\title{
Experimental Study and Thermodynamic Analysis of High Temperature Interactions between Boron Carbide and Liquid Metals
}

\author{
Michael Aizenshtein ${ }^{1}$, Natalya Froumin ${ }^{2}$, Nachum Frage ${ }^{2}$ \\ ${ }^{1}$ Department of Materials, NRC-Negev, Beer-Sheva, Israel \\ ${ }^{2}$ Department of Material Engineering, Ben-Gurion University, Beer-Sheva, Israel \\ Email: ${ }^{*}$ aizensht@bgu.ac.il
}

Received 5 September 2014; revised 23 October 2014; accepted 9 November 2014

Copyright (C) 2014 by authors and Scientific Research Publishing Inc.

This work is licensed under the Creative Commons Attribution International License (CC BY). http://creativecommons.org/licenses/by/4.0/

(c) (i) Open Access

\section{Abstract}

Fabrication of MCCs (Metal Ceramic Composites) and ceramic brazing requires improved wetting properties are often absent in various ceramic/metals systems. This report summarizes a comprehensive study concerning the wetting properties of boron carbide in contact with non-reactive metals such as $\mathrm{Cu}, \mathrm{Au}, \mathrm{Ag}$, and $\mathrm{Sn}$. In order to improve wetting, three different reactive elements were added to the melts; $\mathrm{Si}$, which has relatively high affinity to $\mathrm{C}$, leads to $\mathrm{SiC}$ formation and changes the stoichiometric boron carbide composition $\left(\mathrm{B}_{4} \mathrm{C}\right)$ towards lower carbon content; $\mathrm{Ti}$, which displays high affinity to $\mathrm{B}$, leads to $\mathrm{TiB}_{2}$ formation and free carbon precipitation at the interface; and finally, $\mathrm{Al}$, which forms borocarbide phases at the interface. It was found that $\mathrm{Cu}$ is unusual with respect to boron carbide compared the other non-reactive metals. The most important difference is its ability to dissolve $\sim 25$ at $\%$ of $B$, which makes $B$ adequate as an additive to $\mathrm{Cu}$ in addition to $\mathrm{Si}$, $\mathrm{Ti}$, and $\mathrm{Al}$. When boron was used as an alloying element, its effect on wetting behavior was attributed to altering the boron carbide composition in contact with boron-containing melts. It was concluded that the most important properties of boron carbide that affect wetting phenomena are the relatively low chemical stability and the existence of a wide composition range $\left(\mathrm{B}_{4} \mathrm{C}-\mathrm{B}_{10} \mathrm{C}\right)$. The first property determines the possibility of boron carbide to react with liquid metals (by dissolution or formation of new phases) and the second offers an additional degree of freedom to improve its wetting by changing the composition of the ceramic phase.

\section{Keywords}

Boron Carbide, Titanium Diboride, Silicon Carbide, Metals, Wetting, Interface

\footnotetext{
${ }^{*}$ Corresponding author.
} 


\section{Introduction}

The wetting behavior of molten metals or alloys in contact with ceramic substrates is of crucial importance in a variety of processes, such as the fabrication of metal-ceramic composites (MCCs), the infiltration of ceramic preforms by molten metals, and metal/ceramic or ceramic/ceramic joining. It is not surprising, therefore, that extensive efforts have been devoted to clarifying the underlying factors that determine the wetting behavior and properties of the ceramic-liquid metal interface.

Among the non-oxide ceramics, boron carbide stands out by virtue of its technological importance ensuing from its mechanical properties, elevated thermal conductivity, and thermal shock and oxidation resistance. Boron carbide and boron carbide-based cermets are promising materials for a variety of applications that require elevated hardness, good wear, and corrosion resistance. In fact, many attempts were made to fabricate composites based on boron carbide and aluminum [1]-[3]. Aluminum was the most common metal chosen due to its low density and low melting temperature, which make it suitable for pressure-free infiltration processes. Nevertheless, improved wetting and successful infiltration were achieved above $1200^{\circ} \mathrm{C}$, which introduces undesired effects. Reactions at the ceramic/metal interface cause the formation of undesired brittle phase, including $\mathrm{Al}_{4} \mathrm{C}_{3}$, which is hygroscopic and drastically deteriorates the mechanical properties of the composite. Wetting properties of boron carbide and Ni-based brazing alloys were also studied due to the interest in Ni-based filler metals for high temperature applications [4] [5]. It could be stated that generally ceramics are partially wetted (contact angle, $\Theta$, is much greater than $90^{\circ}$ ) unless a chemical reaction occurs at the ceramic/molten drop interface. The generic reactions are dissolution of the ceramic substrate in the melt or the formation of new phases at the interface [6]-[8], which could promote spreading remarkably.

$\mathrm{B}_{4} \mathrm{C}$ is unique with respect to wetting since it belongs to both the carbides and borides. Carbides can be generally divided to two groups: the first is the narrow composition range carbides such as $\mathrm{SiC}$ and $\mathrm{Al}_{4} \mathrm{C}_{3}$, the second group is carbides such as $\mathrm{TiC}_{x}$ and $\mathrm{ZrC}_{x}(0.5<x<1)$ with a wide composition range. Silicon carbide's wetting properties were extensively investigated because of its use as a structural material in high temperature applications such as reinforcement in metal-matrix composites [9].

Marin et al. [10] showed that that pure $\mathrm{Cu}$ poorly wets $\operatorname{SiC}\left(\theta=140^{\circ}\right.$ at $\left.1100^{\circ} \mathrm{C}\right)$ due to large Si dissolution in molten $\mathrm{Cu}$. The addition of $\mathrm{Si}$ to $\mathrm{Cu}$ inhibits the $\mathrm{Cu}-\mathrm{SiC}$ interface reaction and leads to improved spreading of the SiC substrate $\left(\theta=15^{\circ}, X_{\mathrm{Si}} \approx 0.15\right.$ ). The spreading mechanism was not explained but an attempt towards understanding closely related phenomena was made by Rado et al. [11], who investigated the wetting properties of the $\mathrm{Ag}$ and $\mathrm{SiC} /(\mathrm{Ag}-\mathrm{Si})$ systems. They found that a silver-rich Ag-Si alloy doesn't react with $\mathrm{SiC}$ but wets it fairly well ( $40^{\circ}$ contact angle). They suggested that this behavior is not due to adsorption of $\mathrm{Si}$ at the liquid met$\mathrm{al} / \mathrm{SiC}$ interface but rather to direct bonding between $\mathrm{Ag}$ and $\mathrm{SiC}$, implying that chemical bonds exist at the interface.

The role of stoichiometry is well established in ceramics that display a relatively wide composition range, such as TiC. The study of the $\mathrm{TiC} /(\mathrm{Cu}-\mathrm{Ti}, \mathrm{Al})$ system illustrates the influence of stoichiometry on the wetting behavior [7] [12]. The key factor that controls the interface reaction is the activity of the metal in the carbide. In the case of the stoichiometric carbide (TiC), $\mathrm{Cu}$ is able to dissolve negligible quantities of $\mathrm{Ti}\left(\sim 10^{-6}\right.$ atom fraction at $1400 \mathrm{~K})$, which explains the high contact angle obtained in the $\mathrm{TiC} / \mathrm{Cu}\left(\sim 130^{\circ}\right)$ system. The ability to dissolve relatively large quantities of $\mathrm{Ti}$ in contact with non-stoichiometric $\mathrm{TiC}_{\mathrm{x}}$ improves spreading remarkably ( $\sim 20^{\circ}$ in the $\mathrm{Ti}_{2} \mathrm{C} / \mathrm{Cu}$ system). In practice, the morphology and composition in the vicinity of the interface influences spreading as well as the departure from thermodynamic equilibrium. For example, a metal like Au with high affinity for $\mathrm{Ti}$ in contact with $\mathrm{TiC}$ might cross the graphite-containing region, inducing graphite precipitations that are not wetted by the non-carbide forming metals such as $\mathrm{Au}$ or $\mathrm{Cu}$.

The wetting properties of borides are much less known and investigated compared to carbides. Kharlamov et al. [13] studied the wetting properties of hot-pressed aluminum borides by molten $\mathrm{Al}$ and $\mathrm{Cu}$. Liquid $\mathrm{Al}$ wets all Al-borides.

Muolo et al. [14] [15] studied the wetting behavior in the $\mathrm{ZrB}_{2} / \mathrm{Ag}$, $\mathrm{Cu}$, eutectic $\mathrm{Ag}-\mathrm{Cu}$, and eutectic Ag-Cu-2 wt $\% \mathrm{Zr}$ systems as well in the $\mathrm{TiB}_{2} / \mathrm{Cu}$, Ag-Cu systems. Additions of $2 \mathrm{wt} \% \mathrm{Zr}$ to $\mathrm{Ag}$ and to the eutectic $\mathrm{Ag}-\mathrm{Cu}$ alloy improved wetting remarkably $\left(\sim 15^{\circ}\right.$ and $\sim 50^{\circ}$, respectively). This behavior was attributed to the adsorbed $\mathrm{Zr}$ at the $\mathrm{ZrB}_{2} /$ melt-interface thereby increasing its metallic character. The unique wetting behavior of $\mathrm{TiB}_{2}$ in contact with pure $\mathrm{Cu}$ and $\mathrm{Au}$ was also reported in [16], where the measured contact angles are $\left(\sim 55^{\circ}\right.$ and $\sim 15^{\circ}$, respectively) although only minor quantities of Ti could be dissolved in liquid $\mathrm{Cu}$ and $\mathrm{Au}$ at $1423 \mathrm{~K}\left(\sim 10^{-10}\right.$ and 
$\sim 10^{-7}$ atomic fractions, respectively) and no interface interaction was detected.

Boron carbide, unlike metallic borides, is highly covalent and displays a wide composition between $\mathrm{B}_{10.5} \mathrm{C}$ and $\mathrm{B}_{4} \mathrm{C}(8.8-20$ at\%C) [17] [18]. Regarding chemical interaction with boron carbide, metals can be divided to two groups. Reactive metals, such as $\mathrm{Ti}, \mathrm{Si}, \mathrm{Al}, \mathrm{Fe}, \mathrm{Ni}$, can readily react with boron carbide and form new carbide or boride phases. Boron carbide could easily react with these metals due to relatively low thermodynamic stability compared to other carbides (the reported standard enthalpy of formation of boron carbide is in the range of -38.9 - $71.5 \mathrm{~kJ} / \mathrm{mol}$ boron carbide [19]). The second group contains the so-called non-reactive metals, such as $\mathrm{Cu}, \mathrm{Au}, \mathrm{Ag}$, and $\mathrm{Sn}$, whose interaction with boron carbide leads to limited carbide dissolution or decomposition, without new phase formation as was established by Naidich [20] (the contact angles of $130^{\circ}-140^{\circ}$ were measured between the non-reactive metals and $\mathrm{B}_{4} \mathrm{C}$ ). Nevertheless, the wetting behavior and properties of the $\mathrm{B}_{4} \mathrm{C} /$ nonreactive metal systems have not been the subject of many studies and satisfactory understanding of these systems doesn't exist.

It is known that the wetting of non-oxide ceramics by non-reactive metals could be improved by addition of a reactive component that may significantly alter the metal-ceramic interface. In the case of boron carbide, as will be demonstrated in this article, the alloying element could react with $C$ and form a carbide phase, for instance $\mathrm{SiC}$ if $\mathrm{Si}$ was added. In this case the boron carbide composition changes and the compound composition changes towards higher boron content, $\mathrm{B}_{x} \mathrm{C}(4<x)$, where $x$ depends on the Si content in the melt. If Ti was added to the non-reactive metal, boride phase formation and graphite precipitation take place. It must be noted that carbon solubility in these metals is also extremely low (a few ppm) and carbon precipitation during the interaction may take place. The wide composition range of boron carbide offers an additional degree of freedom that could be used to improve wetting. In the present investigation the interface interaction between boron carbide and liquid alloys based on the non-reactive metals (pure $\mathrm{Cu}, \mathrm{Sn}, \mathrm{Au}$, and $\mathrm{Ag}$ and selected alloys containing $\mathrm{Si}$, $\mathrm{Ti}$, and $\mathrm{Al}$ ) and the wetting phenomena in these systems were studied in order to establish the technological parameters required for producing cermets based on boron carbide.

\section{Experimental}

$\mathrm{B}_{4} \mathrm{C}$ ceramic samples of a near-theoretical density were obtained from hot-pressed powder (Starck) with 1 - 3 $\mu \mathrm{m}$ particle size. The substrate surface for the wetting experiments were polished to the $0.25 \mu \mathrm{m}$ diamond paste level and gently cleaned. Sessile drop experiments were performed at $1423 \mathrm{~K}$ in a vacuum furnace $\left(10^{-5}\right.$ torr $)$ [12]. Alloys were prepared in situ or by an arc furnace, using the appropriate quantities of the relevant elements. Contact angles were measured directly from the magnified profile digital images of the molten metal drop. The solidified drops were cross-sectioned and polished down to $1 \mu \mathrm{m}$ using SiC papers and diamond pastes. The metal-ceramic interface structure and chemical composition were studied using SEM-EDS (energy dispersive spectrometry) and SEM-WDS (wavelength dispersive spectrometry) techniques. X-ray diffraction was used to characterize the composition of the $\mathrm{B}_{4} \mathrm{C}$ substrate. Surface analysis (Auger and XPS) is used to study the composition at the vicinity of the metal/ $\mathrm{B}_{4} \mathrm{C}$ interface.

\section{Results}

The results are presented in the following order. First the thermodynamic analysis of the system is shown, then spreading and interface characterization results are presented and finally a discussion links the two parts.

Although boron carbide is a covalent compound with a very high melting temperature, it isn't stable in contact with various elements such as $\mathrm{Al}, \mathrm{Si}$, Fe or even $\mathrm{Cu}$ which tends to dissolve boron. The following paragraph describes the thermodynamic analysis of the ternary B-C-Cu system followed by the four element B-C-Cu-Si system. Other B-C-Me-Si systems were also investigated. The same approach was used to investigate the B-CMe-Ti system and the B-C-Me (only for $\mathrm{Cu}$ and $\mathrm{Sn}$ )-Al system and is shown for each studied system.

\subsection{The Boron Carbide-Cu and $\mathrm{Cu}-\mathrm{B}$ Systems}

\subsubsection{Thermodynamic Analysis}

According to the $\mathrm{Cu}-\mathrm{C}$ and $\mathrm{Cu}-\mathrm{B}$ phase diagrams, the solubility of carbon in liquid copper at $1200^{\circ} \mathrm{C}$ is very low $\left(x_{\mathrm{C}}^{*}<5 \times 10^{-7}\right.$ atomic fraction [21]) and no carbide phase is present in this system. The Cu-B system displays a eutectic reaction at $13.3 \mathrm{at} \%$ and $1013^{\circ} \mathrm{C}$. The boron solubility in liquid $\mathrm{Cu}$ at $1200^{\circ} \mathrm{C}(1473 \mathrm{~K})$ is about 25 at\%. 
[22]. Since no stable ternary phase in the Cu-B-C system has been reported, an isothermal section for this system may be constructed, as shown in Figure 1. The phase equilibrium regions are denoted by Roman numerals: I-single phase region of the Cu-B-C liquid solution (L.S.); II-two-phase region of L.S. with boron carbide of various compositions; III-two-phase region of L.S. + graphite; IV-three-phase region with L.S., corresponding to Point $\mathrm{O}_{1}$, + graphite $+\mathrm{B}_{4} \mathrm{C}$; V-three-phase region of L.S., corresponding to Point $\mathrm{O}_{2},+\mathrm{B}_{10} \mathrm{C}+$ boron, saturated with $\mathrm{Cu}$; VI-two-phase region with L.S., corresponding to Point $\mathrm{O}_{2}$, + boron, saturated with $\mathrm{Cu}$. Point $\mathrm{O}_{1}$ corresponds to the three-phase equilibrium of the liquid solution $\left(x_{\mathrm{B}}^{0}\right)$ with graphite and stoichiometric boron carbide $\left(\mathrm{B}_{4} \mathrm{C}\right)$. Point $\mathrm{O}_{2}$ corresponds to the three-phase equilibrium of the liquid solution, saturated with $\mathrm{B}\left(x_{\mathrm{B}}^{\prime}\right)$, boron carbide of its lowest carbon content $\left(\mathrm{B}_{10} \mathrm{C}\right)$, and the $\mathrm{Cu}-\mathrm{B}$ solution. The coordinates of the curve $\mathrm{O}_{1}-\mathrm{O}_{2}$ that represents the boundary between single phase and two-phase regions were calculated in detail in [23]. Line 1 (Figure 1), linking unalloyed liquid $\mathrm{Cu}$ with stoichiometric $\mathrm{B}_{4} \mathrm{C}$, crosses the graphite-containing regions. Therefore, in the course of the metal-ceramic interaction graphite precipitation occurs. However, any line, such as Line 2 that links a liquid Cu-B solution having a boron content greater than 2.4 at $\%\left(x_{0}\right)$, with stoichiometric boron carbide, does not cross the graphite-containing regions and graphite precipitation during the metalceramic interaction is avoided. In this latter case, however, if the overall composition of the reacting system corresponds to Point A within the two phase region, the composition of the phases present (melt and carbide) must change according to the end-points of the tie-line (Line 3) that passes through Point A. Careful examination of the figure shows that the boron content of the liquid will decrease $\left(x_{3}<x_{2}\right)$ while the carbide will shift towards areas of higher boron composition. These changes may be due to boron carbide decomposition in the melt at a B/C ratio less than $4 / 1$ or to boron diffusion from the melt into the near surface layer of the substrate.

\subsubsection{Spreading and Interface Characterization}

A high contact angle close to $110^{\circ}$ was observed for $\mathrm{Cu}$ on $\mathrm{B}_{4} \mathrm{C}$ substrate at $1423 \mathrm{~K}$, after 30 min contact (Figure 2(a)). As the result of the interaction of molten copper with the substrate, carbon is released from the carbide and forms a very thin surface layer located at the initial substrate-metal interface. Below that layer, a crater forms, and as it deepens additional carbon is released to form agglomerates dispersed in the molten metal contained within the volume of the crater (Figure 2(b)). It has also been established that boron addition to liquid $\mathrm{Cu}$ prevents the formation of a crater and leads to improved spreading.

It has been established that boron addition (above 2.8 at\%) to liquid $\mathrm{Cu}$ prevents the formation of a crater and leads to improved wetting (Figure 3) [24]. Figure 4 shows that experimental results are in good agreement with the thermodynamic calculations shown above. The contact angle observed is the macroscopic contact angle. Pure $\mathrm{Cu}$ in contact with $\mathrm{B}_{4} \mathrm{C}$ dissolves the substrate (Figure 2) and destroys the flat interface that is mandatory for the validity of the Young-Dupré equation [25] [26] and to the classical meaning of the contact angle. Therefore this result was marked differently.

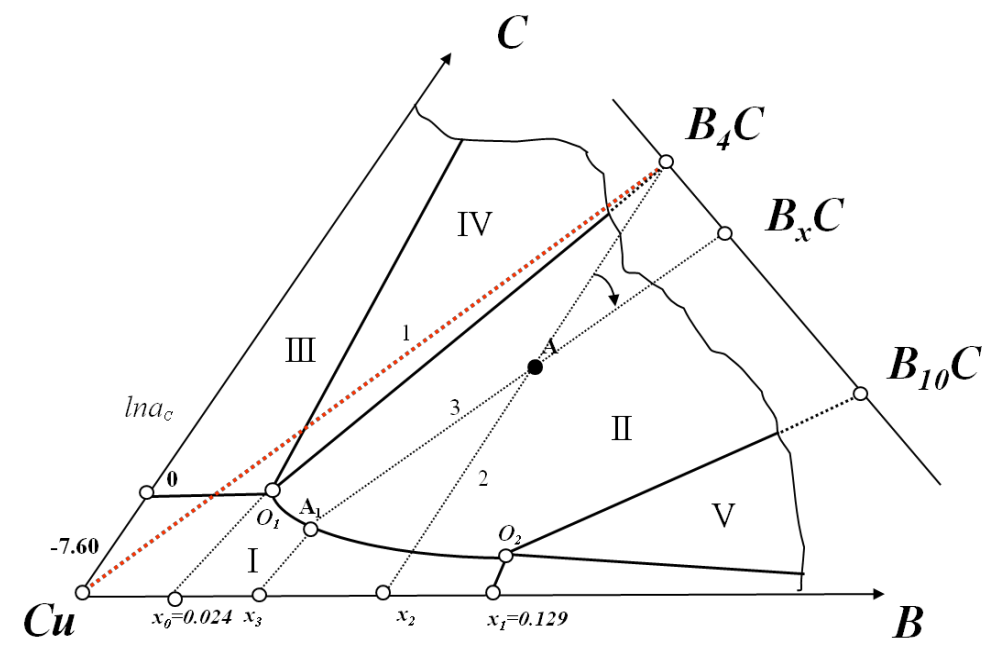

Figure 1. Schematic isothermal section of the ternary Cu-B-C phase diagram at $1473 \mathrm{~K}$ (the $\mathrm{Cu}$-rich corner is out of scale). 

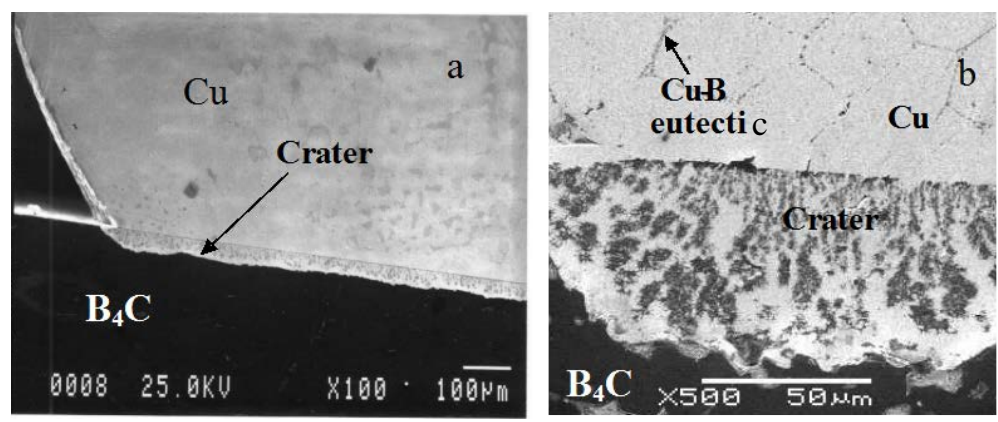

Figure 2. SEM micrographs of the interface after $30 \mathrm{~min}$. contact at $1423 \mathrm{~K}$. (a) High contact angle is clearly visible. A sharp and straight boundary corresponds to the initial ceramic-metal interface. The boundary separates the bulk of the molten drop from the molten metal in the crater; (b) The $\mathrm{B}_{4} \mathrm{C} / \mathrm{Cu}$ interface, at higher magnification. $\mathrm{Cu}-\mathrm{B}$ eutectic was formed during solidification.

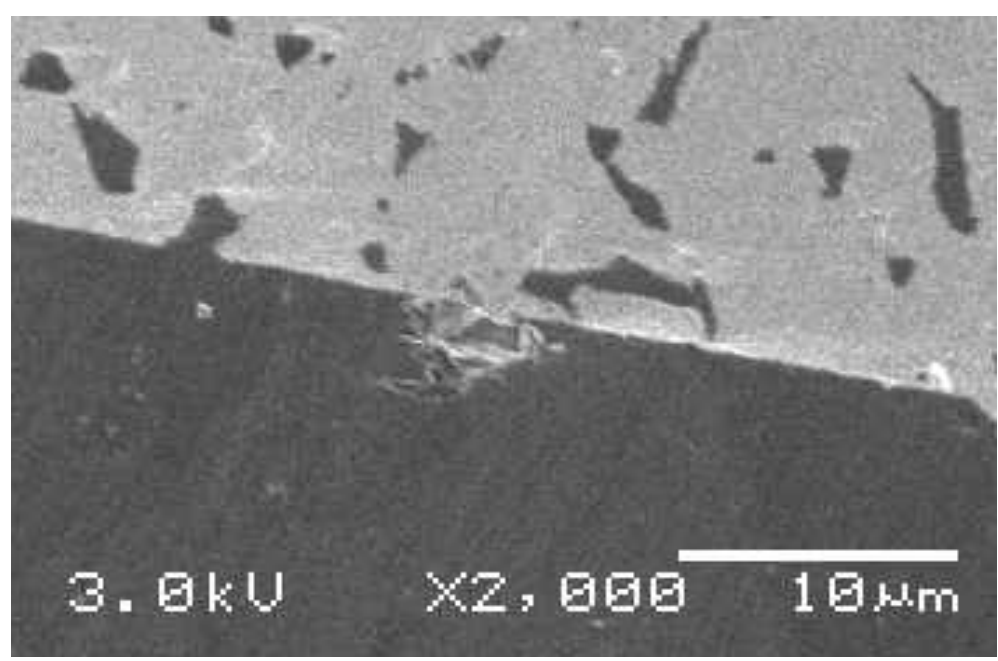

Figure 3. The interface between boron carbide and a Cu-B 2.8 at\% alloy shows a flat interface, without boron dissolution and graphite precipitation.

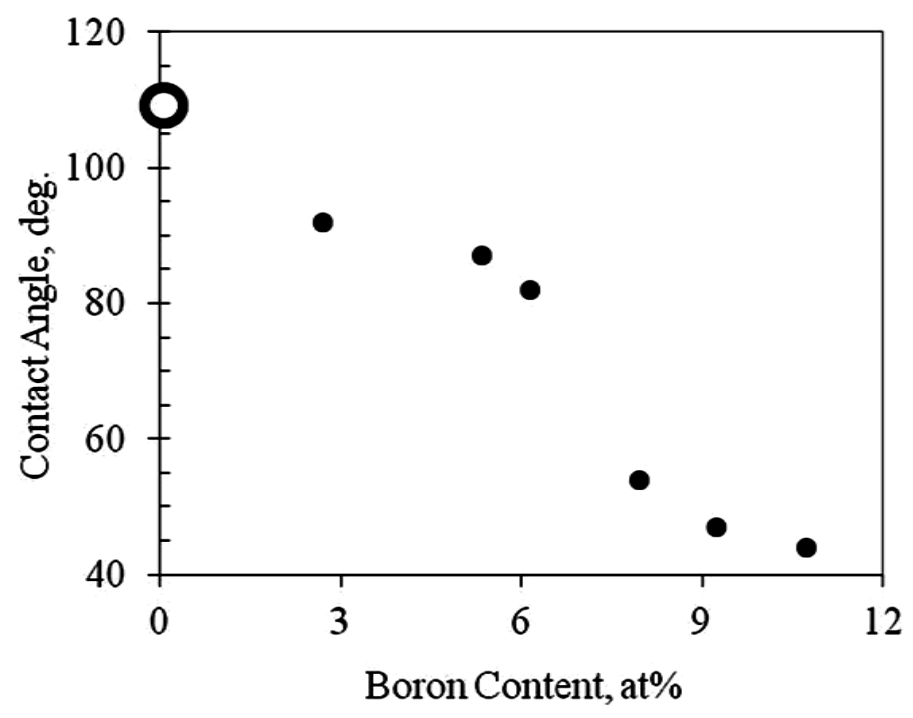

Figure 4. Sessile drop spreading results at $1423 \mathrm{~K}$ in the $\mathrm{B}_{4} \mathrm{C} / \mathrm{Cu}-\mathrm{B}$ system. 


\subsubsection{Discussion}

In spite of the commonly accepted non-reactive and non-wetting behavior of boron carbide by molten copper, the latter attacks boron carbide substrates forming a crater below the contact area. Thermodynamic analysis of the $\mathrm{Cu}$-B-C system in the $\mathrm{Cu}$-rich corner suggests that boron additions to molten $\mathrm{Cu}$ should eliminate the disruption of the boron carbide. The formation of the crater in the boron carbide substrate may be attributed to the dissociation of the carbide in contact with unalloyed copper. Due to differences between the specific weight of $\mathrm{Cu}$ and that of carbon, the carbon released from the carbide floats upward in the melt and forms agglomerates. Boron that is released dissolves in the liquid $\mathrm{Cu}$. In contrast, the interface between boron carbide and copper alloys with about 3 at\% B remained smooth and no evidence of the graphite precipitation was found. This case evidently corresponds to the dashed line 2 in Figure 1. The altering of the boron carbide composition in the nearsurface region close to the interface with liquid $\mathrm{Cu}-\mathrm{B}$ melt provides additional confirmation of the validity of the thermodynamic analysis. Similar interface phenomena were observed in the $\mathrm{TiC}_{x}$-Cu system, in which changes of the substrate composition, within the stoichiometric range of the titanium carbide phase, and the wetting behavior were affected by $\mathrm{Ti}$ additions to liquid $\mathrm{Cu}$ [27].

\subsection{The Boron Carbide/(Me-Si, $\mathrm{Me}=\mathrm{Cu}, \mathrm{Au}, \mathrm{Sn}, \mathrm{Ag})$ Systems}

The boron carbide/(Me-Si) study is divided into two parts. The $\mathrm{B}_{4} \mathrm{C} /(\mathrm{Cu}-\mathrm{Si})$ system, due the strong boron dissolution in liquid $\mathrm{Cu}$ at $1423 \mathrm{~K}$, is more complicated than the other Me-Si systems. Therefore the study is focused on this system, and the other systems, which are less complex, broaden the understanding of the interactions in the $\mathrm{B}_{4} \mathrm{C} /($ non-reactive metals-Si) systems.

\subsubsection{Thermodynamic Analysis of the B-C-Si and the B-C-Si-Me ( $\mathrm{Cu}, \mathrm{Au}, \mathrm{Sn}$ ) Systems}

A calculated isothermal section of the Si-B-C system at $1400 \mathrm{~K}$ has been published by Seifert [28] (Figure 5). Over its high carbon content range, namely $\mathrm{B}_{x} \mathrm{C}$ with $4<x<6.6$, boron carbide is in two-phase equilibrium with $\mathrm{SiC}$ or in three-phase equilibrium with $\mathrm{Si}$ and $\mathrm{SiC}$. Only at lower carbon content does silicon boride $\mathrm{SiB}_{3}$ appear and coexist with boron carbide $\mathrm{B}_{6.6} \mathrm{C}$. Since copper does not form compounds with either carbon or boron, it may be considered as a diluting agent of silicon, which decreases the silicon activity. In the case of the Cu-B-C-Si system, the reaction between boron carbide and the dissolved Si in molten copper may be expressed as:

$$
X[\mathrm{Si}]+\mathrm{B}_{4} \mathrm{C}=x \mathrm{SiC}+\mathrm{B}_{4} \mathrm{C}_{1-x}
$$

A detailed thermodynamic of the quaternary Cu-Si-C-B system was performed in [23]. Although the expres-

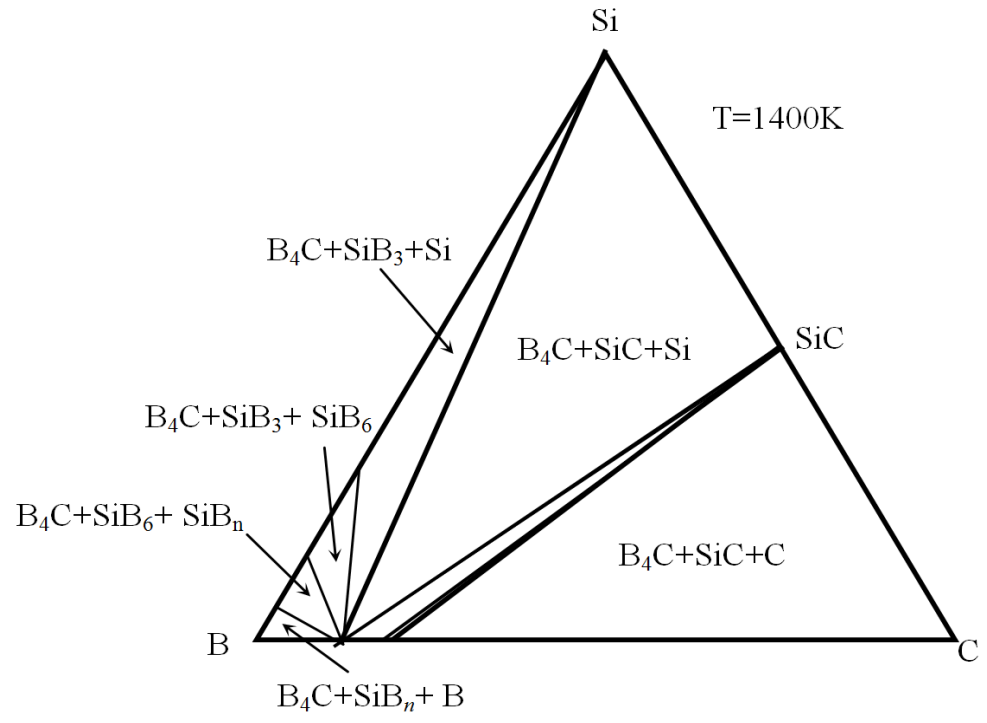

Figure 5. Isothermal section of the ternary B-C-Si phase diagram at $1400 \mathrm{~K}$ [28]. 
sion describes the actual reaction, it is not possible to derive the equilibrium parameters because the standard formation energies for $\mathrm{B}_{4} \mathrm{C}_{1-x}$ are unknown. In order to overcome this obstacle a different approach was used. For a thermodynamic analysis of $\mathrm{SiC}$ being formed by carbon that originated in non-stoichiometric boron carbide and $\mathrm{SiB}_{3}$ being formed from $\mathrm{B}$ and $\mathrm{Si}$ dissolved in liquid $\mathrm{Cu}$, the chemical reactions considered are:

$$
\begin{gathered}
(\mathrm{Si})+[\mathrm{C}]=\mathrm{SiC} \\
(\mathrm{Si})+3[\mathrm{~B}]=\mathrm{SiB}_{3}
\end{gathered}
$$

where the parentheses signify that $\mathrm{Si}$ and B are in the liquid solution and the brackets that carbon is in the B-C solid solution, within the composition limits corresponding to the stability range of the boron carbide phase. The thermodynamic properties of the melt were treated by the Redlich-Kister approach [29]. According to this approach the thermodynamic properties of the multi-component liquid solution could be expressed by taking into account the thermodynamic properties of the binary solutions (expressed by the interaction parameters $L^{i}$, $i=0,1,2 \cdots)$. The different binary systems, the coefficients $L_{\mathrm{Me}-\mathrm{Si}}^{0}$ and $L_{\mathrm{Me}-\mathrm{Si}}^{1}$, were derived at $1423 \mathrm{~K}$ and are summarized in Table 1.

Figure 6 shows the equilibrium results. Each point on the curve corresponds to a certain boron carbide composition $\left(X_{\mathrm{C}}\right)$ in equilibrium with the liquid Me-Si-B solution at a definite composition of the melt. The area above the curve corresponds to the two-phase region consisting of boron carbide of various compositions with the liquid solution. The region below the curve corresponds to the three phase equilibrium: Boron carbide of various compositions, SiC, and the liquid solution. The coordinates of the invariant Point A determine the para-

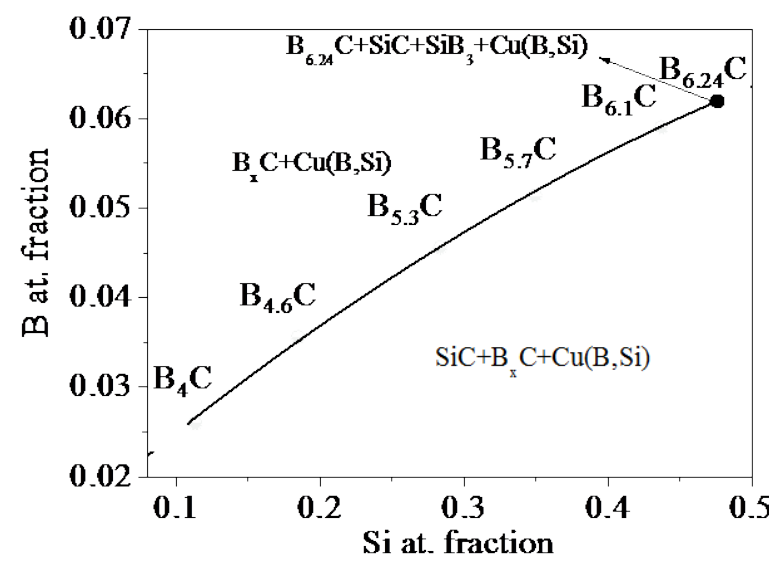

(a)

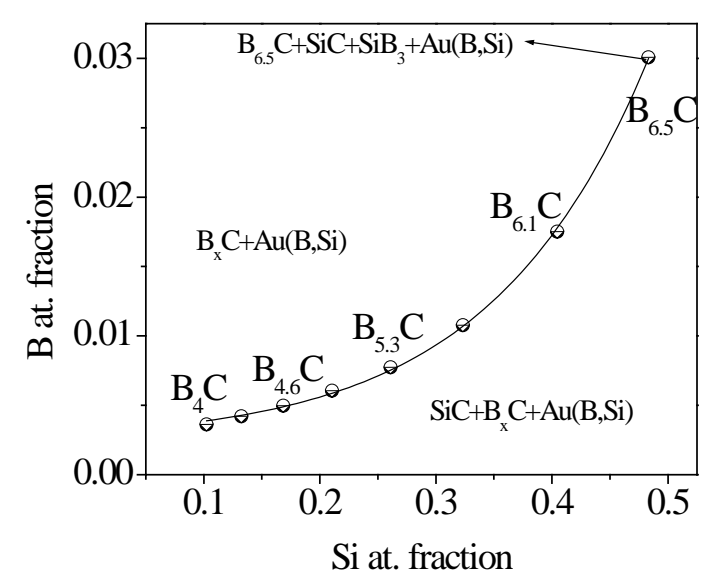

(b)

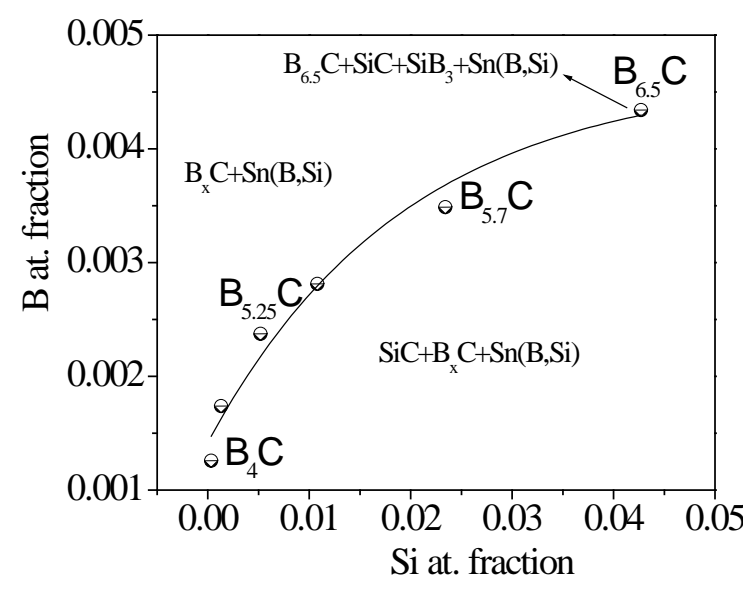

(c)

Figure 6. Phase equilibria in the Me-boron carbide-silicon melts ( $\mathrm{Me}=\mathrm{Cu}, \mathrm{Au}, \mathrm{Sn})$ at 1423K. Cu-boron carbide-Si (a). Auboron carbide-Si (b); Sn-boron carbide-Si (c). 
Table 1. The calculated $L_{\mathrm{Me-Si}}^{0}$ and $L_{\mathrm{Me}-\mathrm{Si}}^{1}$ for the binary Cu-Si, Au-Si, and Sn-Si liquid solutions at $1423 \mathrm{~K}$. $L_{\mathrm{Me-B}}^{0} \quad$ was estimated according to the binary phase diagrams.

\begin{tabular}{ccc}
\hline System & $L^{0}[\mathrm{~J} / \mathrm{mol}]$ & $L^{1}[\mathrm{~J} / \mathrm{mol}]$ \\
\hline Cu-Si & $-46,862$ & 16,636 \\
Cu-B & 20,000 & 0 \\
Au-Si & $-39,300$ & 21,210 \\
Au-B & 40,000 & 0 \\
Sn-Si & 23,960 & -1950 \\
Sn-B & 55,000 & 0 \\
\hline
\end{tabular}

meters of the four phase equilibrium where, in addition to the phases mentioned above, silicon boride $\left(\mathrm{SiB}_{3}\right)$ appears. The limit composition of the boron carbide phase that may be in equilibrium with the melt and $\mathrm{SiC}$ corresponds to $\sim \mathrm{B}_{6.5} \mathrm{C}$. This value is in good agreement with the composition of boron carbide derived from the reported data for ternary Si-B-C phase diagram [28] (Figure 5). According to the calculated diagrams (Figure 6), the Me-Si alloys that are in equilibrium with $\mathrm{B}_{4} \mathrm{C}$ and $\mathrm{SiC}$ contain 11 at $\% \mathrm{Si}$ for the $\mathrm{B}_{4} \mathrm{C} / \mathrm{Cu}-\mathrm{Si}, 10$ at $\% \mathrm{Si}$ for the $\mathrm{B}_{4} \mathrm{C} / \mathrm{Au}-\mathrm{Si}$ system, and 0.03 at\% $\mathrm{Si}$ for the $\mathrm{B}_{4} \mathrm{C} / \mathrm{Sn}-\mathrm{Si}$ system, which reflect the departure from ideality (negative or positive) of the various liquid solutions.

\subsubsection{Spreading and Interface Characterization}

The equilibrium contact angles at $1423 \mathrm{~K}$ as a function of the alloying element composition are shown in Figure 7.

The interface characterization in the $(\mathrm{Sn}-\mathrm{Si}) / \mathrm{B}_{4} \mathrm{C}$ is shown in Figure 8. A very thin (less than $\left.1 \mu \mathrm{m}\right)$ continuous $\mathrm{SiC}$ layer was detected by WDS analysis at the interface. In this case, the presence of free carbon is avoided; the extremely thin $\mathrm{SiC}$ layer formed on the substrate is wetted by the (Sn-Si) molten alloy. At the interface of boron carbide with Cu-Si alloys containing less than 13 at\% Si, the presence of a small crater with a thin discontinuous layer on its top was observed (Figure 9). According to X-ray mapping of C, this region consists of very fine graphite particles within the $\mathrm{Cu}-\mathrm{Si}$ melt. There is no evidence for any $\mathrm{SiC}$ phase formation and the interface is similar to that formed in the $\mathrm{B}_{4} \mathrm{C} / \mathrm{Cu}$ system. The formation of $\mathrm{SiC}$ takes place at the $\mathrm{B}_{4} \mathrm{C} /(\mathrm{Cu}-15$ at\% Si) interface (Figure 10).

EDS and WDS quantitative analysis confirm that the interface particles are SiC. It is important to point out that at the first stages of the interaction, when the silicon carbide particles were already formed, the contact angle is greater than $90^{\circ}$. Qualitative line scans (Figure 11(b)) show that a silicon layer covers large portions of the composite SiC-Cu layer. This layer, which lies on the liquid side of the initial interface, formed during the solidification of the molten metal drop and can be attributed to the decreased solubility of Si in molten Cu-Si alloy with decreasing temperature. At several locations, relatively large $\mathrm{SiB}_{3}$ particles were detected contiguous to the solid, whether Si (Figure 11) or initial $\mathrm{B}_{4} \mathrm{C}$, as shown below. These particles apparently nucleated in the course of the melt cooling and provide unambiguous proof of the presence of a significant boron concentration within the melt. The crater that was formed within the boron carbide substrate consists of SiC particles with entrapped pockets of the Cu-Si-B melt, reminiscent of that of the carbon agglomerates shown in Figure 2(b) and Figure 9. The presence of silicon boride particles, which were formed during solidification and are contiguous to the flat interface (Figure 11(f)), further confirm the enrichment of the melt by boron. The line scan and mappings underline the complex nature of the molten alloy-boron cabide interface after solidification. Going from the molten Cu-alloy melt towards the substrate, this consists of heterogeneously nucleated silicon boride particles and a quasi-continuous Si layer, both formed during the solidification of the molten alloy due to the greatly reduced solubility of $\mathrm{B}$ and $\mathrm{Si}$ in solid $\mathrm{Cu}$. At the initial (prior to crater formation) molten metal boron carbide interface, a quasi-continuous SiC layer is present. The crater volume is filled with additional SiC intermixed with entrapped pockets of solidified Cu-Si-B alloy, with most of the latter adjacent to the roughened boron carbide substrate surface. 


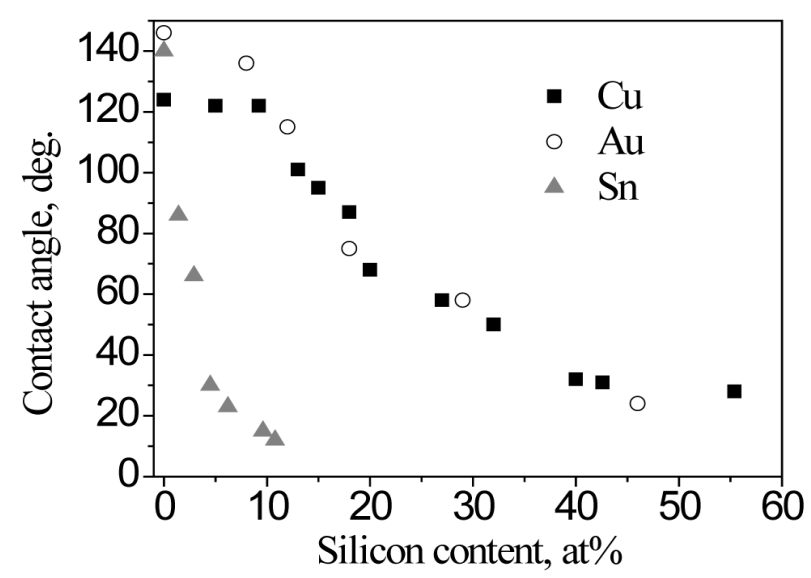

Figure 7. Sessile drop spreading results at $1423 \mathrm{~K}$ in the $\mathrm{B}_{4} \mathrm{C} /$ $\mathrm{Me}=(\mathrm{Cu}, \mathrm{Au}, \mathrm{Sn})-\mathrm{Si}$ systems.

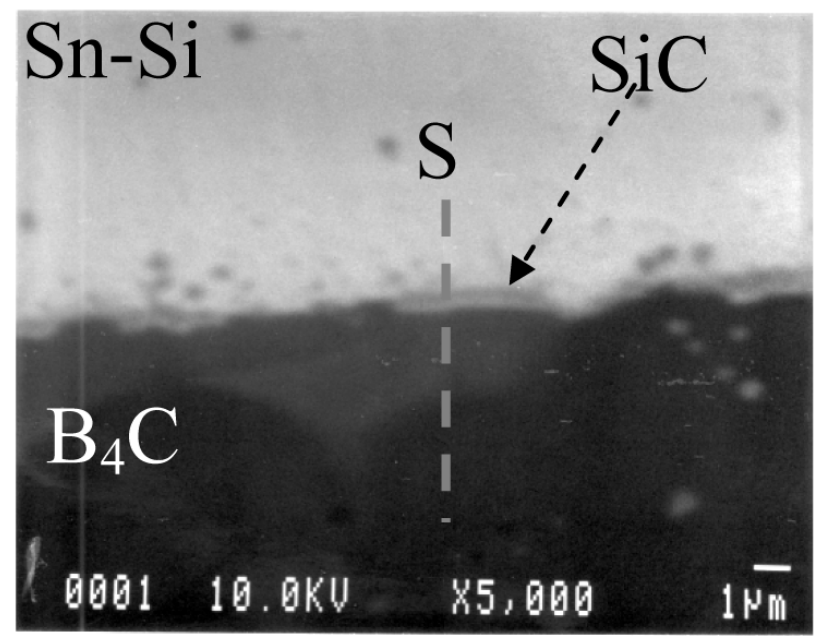

Figure 8. The interface of $\mathrm{B}_{4} \mathrm{C}$ and $\mathrm{Sn}-8$ at\% Si melt (after 90 min at $1423 \mathrm{~K}$ ), a thin continuous $\mathrm{SiC}$ layer was formed.

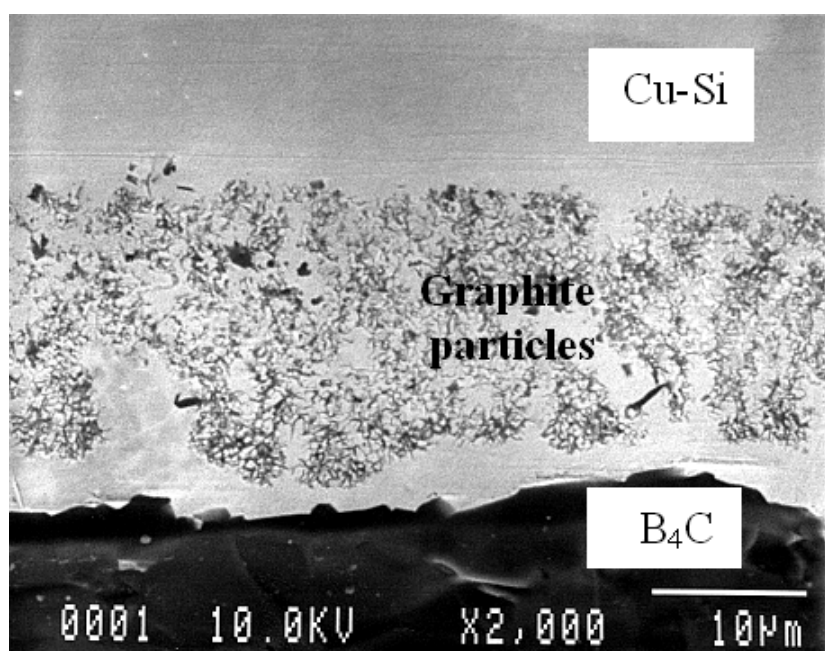

Figure 9. SEM image at the $\mathrm{B}_{4} \mathrm{C} /(\mathrm{Cu}-9$ at\% Si) interface after $90 \mathrm{~min}$ at $1423 \mathrm{~K}$. 

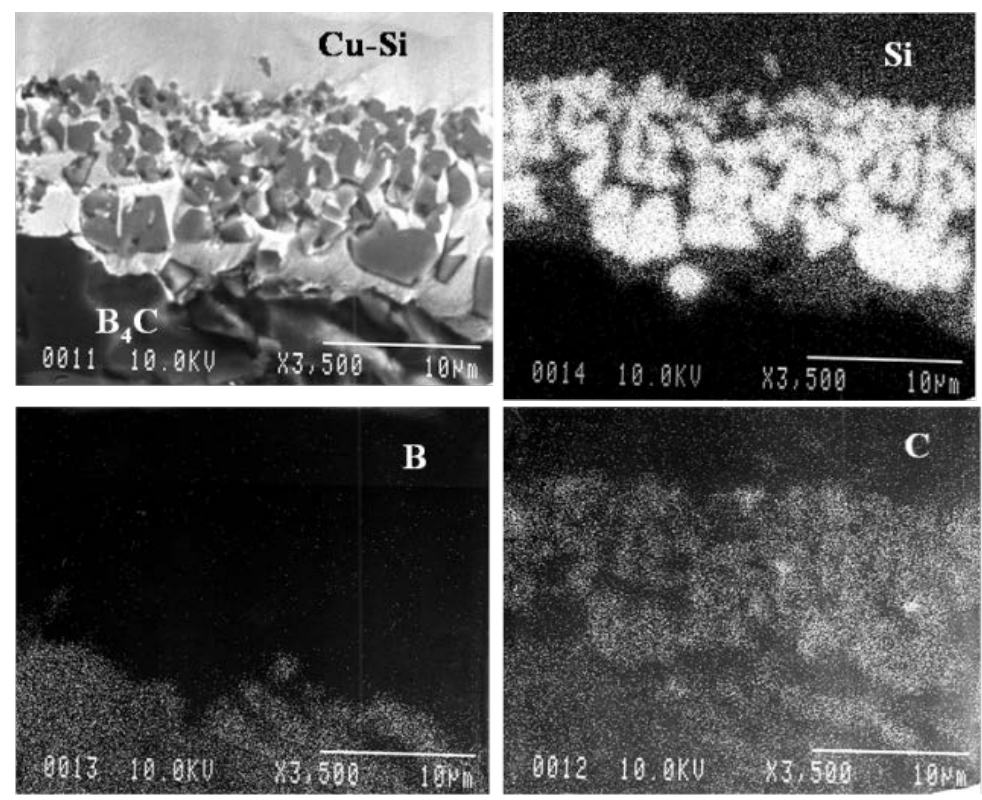

Figure 10. SEM and X-ray mapping images at the $\mathrm{B}_{4} \mathrm{C} /(\mathrm{Cu}-15$ at $\% \mathrm{Si})$ interface after $90 \mathrm{~min}$ at $1423 \mathrm{~K}$.
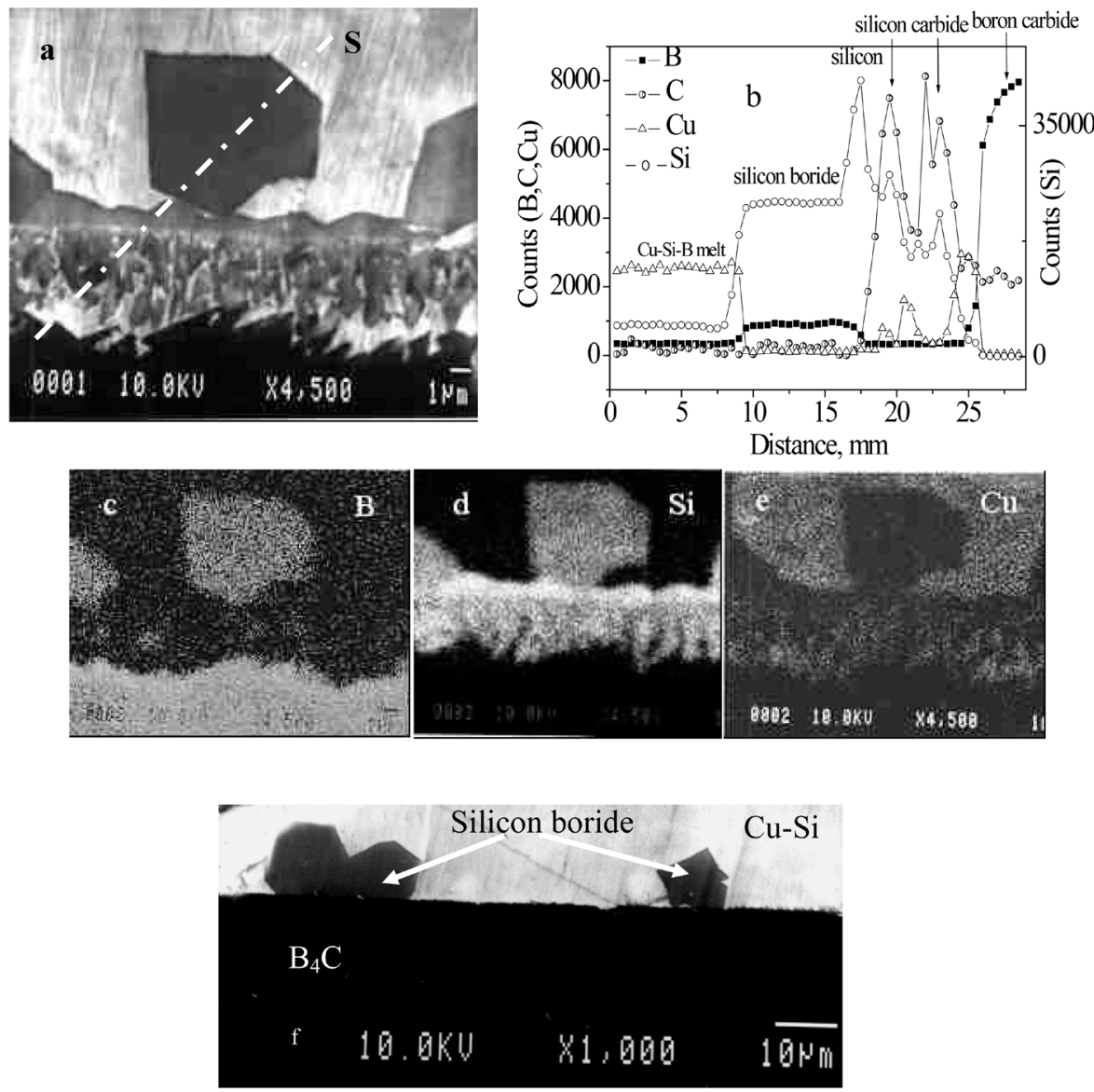

Figure 11. SEM micrograph of the $\mathrm{B}_{4} \mathrm{C} /(\mathrm{Cu}-40$ at\% Si) interface (a). WDS line-scan of boron, carbon, silicon, and copper across the interface (b). Boron, silicon, and copper mappings (c, d, and e, respectively). Silicon boride particles that precipitated in contact with the flat interface near the triple line (f). 


\subsubsection{Discussion}

Alloying the metals with silicon provides another option for the metal-ceramic interaction. Boron carbide exists over a wide range of carbon content, and its interaction with an element with a high affinity to carbon, like Si, leads to the formation of a new carbide phase and to a shift of the boron carbide composition to higher boron content. This interaction depends on the activity of $\mathrm{Si}$ in the molten solutions, and on the carbon activity in the boron carbide phase at various compositions. In the binary systems $\mathrm{Cu}-\mathrm{Si}$ and $\mathrm{Au}-\mathrm{Si}$ the liquid solutions display a strong negative departure from ideality, whereas the Sn-Si liquid solution has a strong positive departure. According to the phase equilibria in the $\mathrm{B}_{4} \mathrm{C} / \mathrm{Me}-\mathrm{Si}$ systems (Figure 6), the Me-Si alloys that are in equilibrium with $\mathrm{B}_{4} \mathrm{C}$ and $\mathrm{SiC}$ contain 12 at\% $\mathrm{Si}$ for the $\mathrm{B}_{4} \mathrm{C} / \mathrm{Cu}-\mathrm{Si}$ system and 10 at $\% \mathrm{Si}$ for the $\mathrm{B}_{4} \mathrm{C} / \mathrm{Au}-\mathrm{Si}$ system. On the other hand, even very small Si additions to the liquid Sn ( $<0.1$ at\%) lead to $\mathrm{SiC}$ formation from the carbon that originated from the boron carbide phase.

For the $\mathrm{B}_{4} \mathrm{C} /(\mathrm{Au}-\mathrm{Si})$ and $\mathrm{B}_{4} \mathrm{C} /(\mathrm{Sn}-\mathrm{Si})$ systems, due to the very limited boron solubility in the melts, boron carbide does not dissociate and a flat interface is observed. A direct interaction between the Si dissolved in the metal and the boron carbide takes place, resulting in the formation of a continuous thin $\mathrm{SiC}$ layer that covers the substrate surface. The measured contact angles reflect the characteristic of ( $\mathrm{Au}-\mathrm{Si})$ and $(\mathrm{Sn}-\mathrm{Si})$ melts on silicon carbide. The equilibrium contact angles that were obtained in this study are in a good agreement with the experimental results for the $\mathrm{SiC} /(\mathrm{Au}-\mathrm{Si})$ and $\mathrm{SiC} /(\mathrm{Sn}-\mathrm{Si})$ systems reported elsewhere [30] [31].

The following schema is proposed for the interaction and wetting in the $\mathrm{B}_{4} \mathrm{C} /(\mathrm{Cu}-\mathrm{Si})$ system (Figure $12(\mathrm{~d})$ ) and the $\mathrm{B}_{4} \mathrm{C} /(\mathrm{Au}, \mathrm{Sn}-\mathrm{Si})$ systems (Figure 12(e)). The first step (Figure 12(a)) consists of the dissolution of boron in the melt, release of carbon, and formation of a crater with graphite agglomerates. At the second stage (Figure 12(b)), silicon dissolved in the melt reacts with graphite and silicon carbide particles are formed. The metal drop does not yet wet the substrate. In the course of the third stage a change of the substrate composition takes place, the boron concentration in the melt increases, boron diffuses to the drop's periphery and interacts with the substrate surface, and the conditions for wetting are achieved in the vicinity of the triple line (Region A, Figure 12(c), Figure 12(d)). Finally, the metal drop spreads over the sub-stoichiometric boron carbide.

Interface structure and wetting behavior in the $\mathrm{B}_{4} \mathrm{C} /(\mathrm{Me}-\mathrm{Si})$ systems are determined by the solubility of boron in the melt and the interaction between silicon dissolved in the melts with the boron carbide substrate. The equilibrium contact angle in the $\mathrm{B}_{4} \mathrm{C} /(\mathrm{Cu}-\mathrm{Si})$ is affected by the composition of the near-surface layer of the boron carbide that has a higher boron content. Wetting in the $\mathrm{B}_{4} \mathrm{C} /(\mathrm{Au}-\mathrm{Si})$ and $\mathrm{B}_{4} \mathrm{C} /(\mathrm{Sn}-\mathrm{Si})$ systems reflects the formation of a $\mathrm{SiC}$ interlayer, and the spreading behavior of the $\mathrm{SiC} /(\mathrm{Au}-\mathrm{Si})$ and $\mathrm{SiC} /(\mathrm{Sn}-\mathrm{Si})$ systems.

\subsection{The Boron Carbide (Me-Ti, $\mathrm{Me}=\mathrm{Cu}, \mathrm{Au}, \mathrm{Sn}, \mathrm{Ag}$ ) Systems}

\subsubsection{Thermodynamic Analysis}

The sequence of phase formation when pure Ti reacts with stoichiometric boron carbide phase may be analyzed according to the dashed line in the ternary B-C-Ti phase diagram [32] (Figure 13) that links the Ti corner with
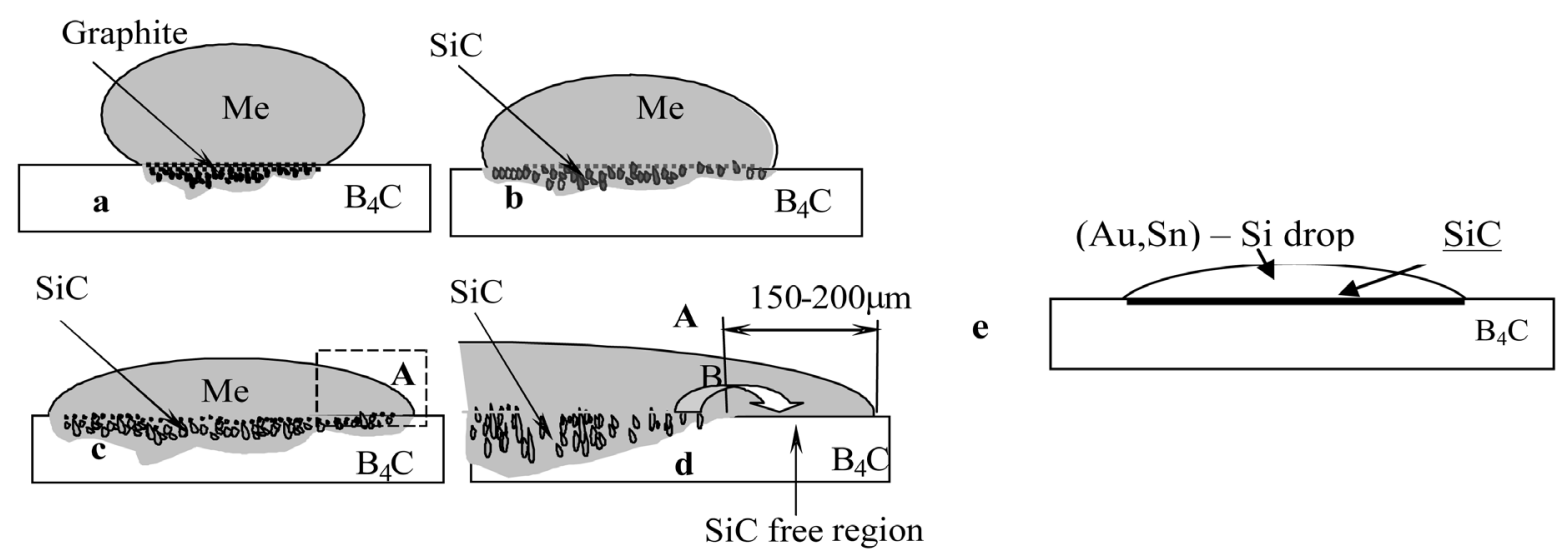

Figure 12. The interaction stages at the boron carbide and Cu-Si melt interface (a-d). (e) The interaction and wetting between boron carbide and ( $\mathrm{Au}, \mathrm{Sn}-\mathrm{Si}$ ) melt alloys is due to direct wetting of the $\mathrm{SiC}$ layer formed at the boron carbide-melt interface. 


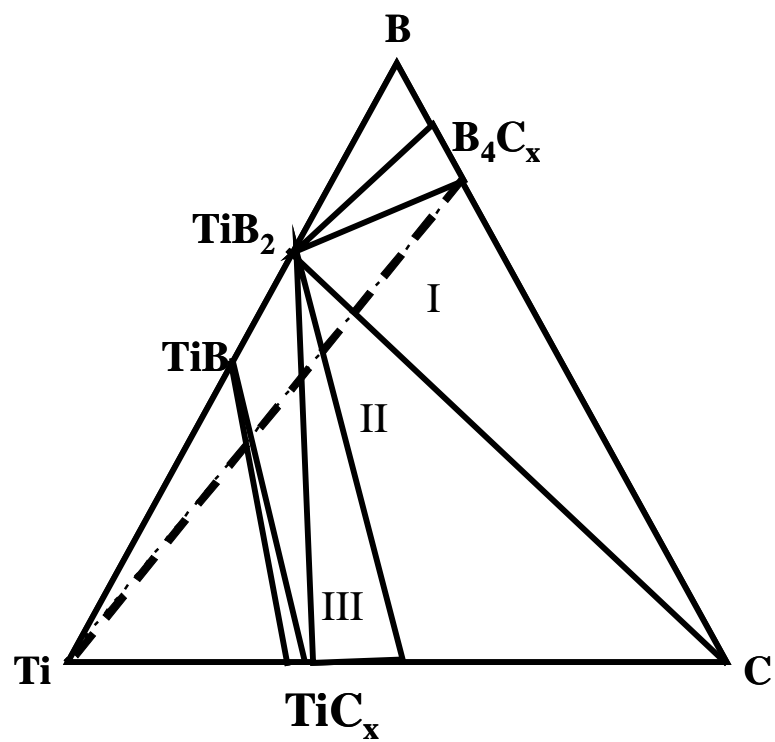

\begin{abstract}
Figure 13. Schematic view of the B-C-Ti ternary phase diagram at $1400 \mathrm{~K}$. Region I corresponds to $\mathrm{TiB}_{2}+$ graphite + $\mathrm{B}_{4} \mathrm{C}$; Region II $\mathrm{TiB}_{2}+$ graphite $+\mathrm{TiC}$, and Region III $\mathrm{TiB}_{2}+$ $\mathrm{TiC}_{x}$.
\end{abstract}

the point corresponding to boron carbide. Each point on this line defines the relative amounts of the phases that are in equilibrium. At a low Ti/ $\mathrm{B}_{4} \mathrm{C}$ mass ratio, the system is in the three-phase Region (I) $\mathrm{TiB}_{2}+$ graphite $+\mathrm{B}_{4} \mathrm{C}$. Thus, $\mathrm{TiB}_{2}$ and graphite are the first phases that are formed at the boron carbide/titanium interface. The formation of the TiC phase takes place only when boron carbide is consumed (or there is no direct contact between melt and substrate) and carbide is in equilibrium with $\mathrm{TiB}_{2}$ and graphite (Region II). At higher Ti content (or if the released free carbon is completely consumed), the conditions for $\mathrm{TiB}_{2}$ coexisting with non-stoichiometric titanium carbide phase $\left(\mathrm{TiC}_{x}\right.$ ) may be achieved (Region III).

The non-reactive metals do not form any stable carbide or boride phases. Thus, the influence of these metals as solvents for Ti may be attributed to their effect on the respective activities of titanium, carbon, and boron in the liquid solutions. A detailed thermodynamic analysis was done in [28], which takes into account the condition in which $\mathrm{TiC}$ and $\mathrm{TiB}_{2}$ could be formed.

\title{
3.3.2. Spreading and Interface Characterization
}

The values of the equilibrium contact angle for the $\mathrm{B}_{4} \mathrm{C} /(\mathrm{Me}-\mathrm{Ti})$ systems as a function of the Ti content are shown in Figure 14. The addition of small quantities of Ti (less than 1 at\%) are needed to achieve wetting of $\mathrm{B}_{4} \mathrm{C}$ by $\mathrm{Cu}, \mathrm{Sn}$, and $\mathrm{Ag}$ alloys. For the Au-Ti alloys, wetting conditions were reached when the Ti content was greater than 3 at\%.

According to the SEM analysis, the interface structures in the $\mathrm{B}_{4} \mathrm{C} /(\mathrm{Sn}-\mathrm{Ti}), \mathrm{B}_{4} \mathrm{C} /(\mathrm{Ag}-\mathrm{Ti})$, and $\mathrm{B}_{4} \mathrm{C} /(\mathrm{Au}-\mathrm{Ti})$ systems were similar. In all these systems, a very thin bi-layered structure was observed between the substrate and the metal drop (for Au-3.4 at\% Ti alloy and Ag-0.9 at\% Ti alloy, Figure 15(a) \& Figure 15(c)). Qualitative WDS scan (Figure 15(b) \& Figure 15(d)) shows that the first layer, adjacent to $\mathrm{B}_{4} \mathrm{C}$, contains Ti and B, while the second layer contains $\mathrm{Ti}$ and $\mathrm{C}$. On approaching the triple line, the thickness of the reaction product layers decreases continuously down to about $0.1 \mu \mathrm{m}$, as shown for the $\mathrm{B}_{4} \mathrm{C} /(\mathrm{Ag}-\mathrm{Ti})$ system (Ag-0.9 at\% Ti alloy, Figure 16).

The interface between $\mathrm{B}_{4} \mathrm{C}$ and $\mathrm{Cu}-\mathrm{Ti}$ melts (Cu-5.4 at\% Ti alloy, Figure 17) is quite different from the interfaces shown above. Due to the strong tendency of $\mathrm{B}_{4} \mathrm{C}$ to decompose in $\mathrm{Cu}$ melts, the interaction at the interface leads to significant substrate dissolution and to crater formation (Figure 17(a)). The crater is filled with graphite agglomerates distributed in the melt, as was previously observed in the $\mathrm{B}_{4} \mathrm{C} / \mathrm{Cu}$ and $\mathrm{B}_{4} \mathrm{C} /(\mathrm{Cu}-\mathrm{Si})$ systems. At some distance from the initial metal/ceramic interface, the presence of a convoluted $\mathrm{TiB}_{2}$ "lace" approximately $30 \mu \mathrm{m}$ wide was observed (Figure 17(c)). The presence of the discontinuous thin $\mathrm{TiB}_{2}$ layer can be seen just at 


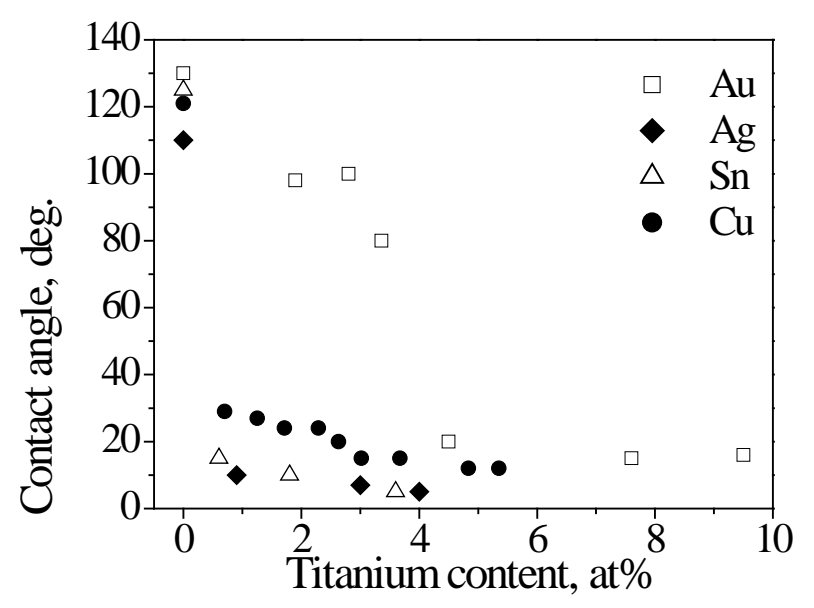

Figure 14. Sessile drop spreading results at $1423 \mathrm{~K}$ in the $\mathrm{B}_{4} \mathrm{C} / \mathrm{Me}=(\mathrm{Ag}, \mathrm{Sn}, \mathrm{Cu})-\mathrm{Ti}$ systems as a function of the Ti content in the liquid solutions.
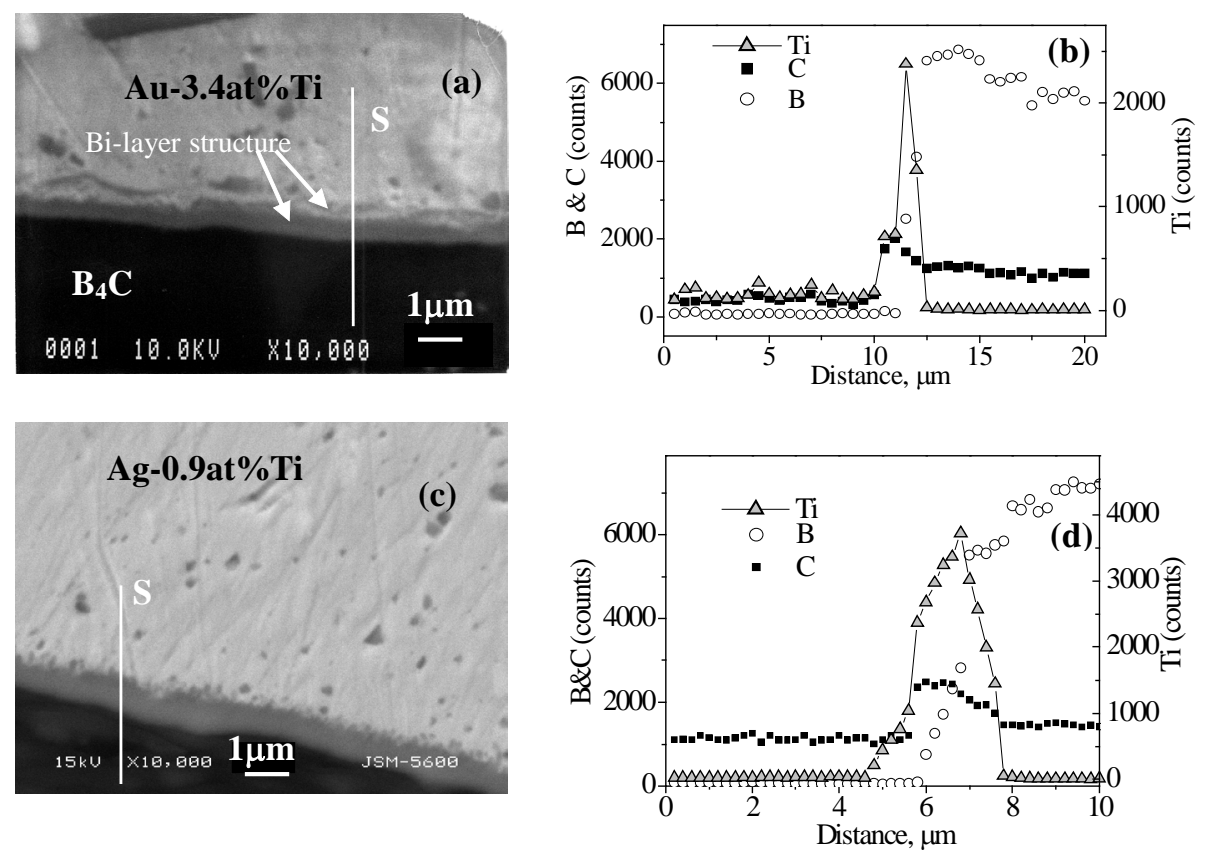

Figure 15. SEM micrographs (a, c) and WDS line scan (b, d) at the $\mathrm{B}_{4} \mathrm{C} /(\mathrm{Me}-\mathrm{Ti})$ interface.

the initial metal/ceramic interface. The titanium content in the crater, between the "lace" and the substrate is practically zero (Cu-1.25 at\% Ti alloy, Figure 17(b)), while above the "lace" Ti is still present in the melt (the Ti line scan, compare the Ti level below $20 \mu \mathrm{m}$ with that beyond $25 \mu \mathrm{m}$ ). The "lace" is detached from the initial ceramic surface along the whole width of the drop, while at the triple line, a $\mathrm{TiB}_{2}$ layer is still connected to the substrate. According to the above results it seems that spreading takes place over the progressively formed $\mathrm{TiB}_{2}$ layer.

\subsubsection{Discussion}

The interface structure and composition of boron carbide $\mathrm{B}_{4} \mathrm{C}$ in contact with Me-Ti melts $(\mathrm{Me}=\mathrm{Sn}, \mathrm{Ag}$, or $\mathrm{Au})$ are determined by the direct interaction between Ti dissolved in the melt and the $\mathrm{B}_{4} \mathrm{C}$ substrate. Initially, the interface is covered by a continuous $\mathrm{TiB}_{2}$ layer and the released free carbon reacts with Ti to form stoichiometric titanium carbide in equilibrium with graphite. Next, after the free carbon is consumed completely, the titanium 


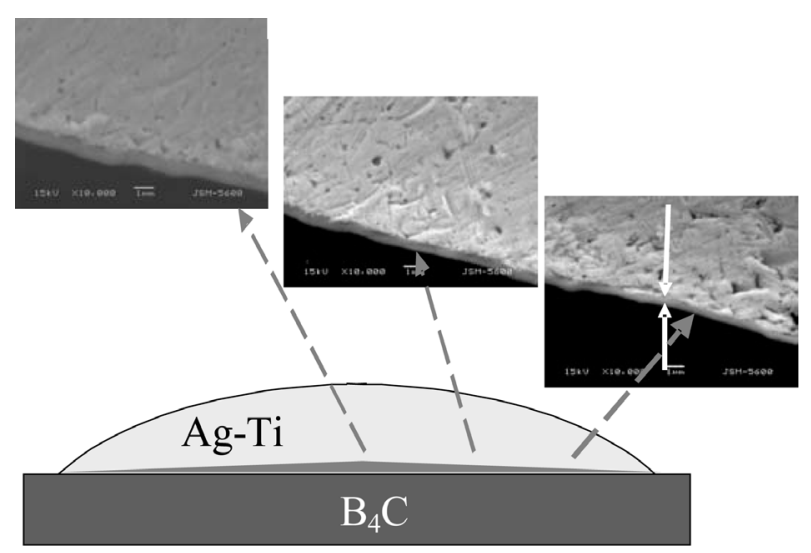

Figure 16. The interface product layer evolution from the middle of the drop to the triple line in the $\mathrm{B}_{4} \mathrm{C} /(\mathrm{Ag}-\mathrm{Ti})$ system.
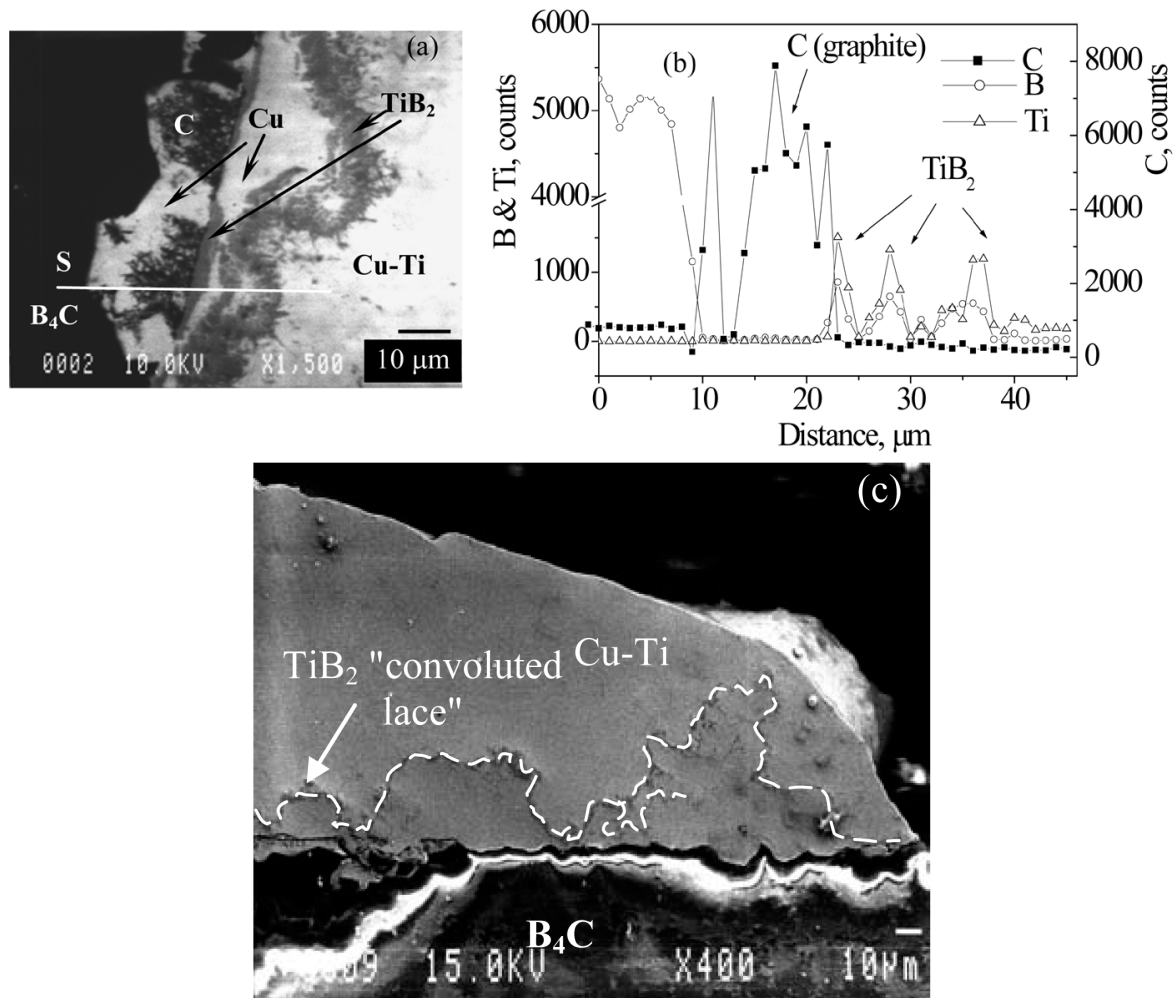

Figure 17. SEM micrograph, the interface morphology: $\mathrm{B}_{4} \mathrm{C}+$ graphite $+\mathrm{TiB}_{2}+\mathrm{Cu}$ (Ti) Solution are observed (a); WDS line scan of the $\mathrm{B}_{4} \mathrm{C} /(\mathrm{Cu}-\mathrm{Ti})$ interface (b); The location of the $\mathrm{TiB}_{2}$ layer with respect to the drop and the substrate (c).

carbide may change its composition in accordance with the activity of titanium in the melt. At the triple line, the observed spreading angle corresponds to that determined by the contact between $\mathrm{TiC}_{x}$ and the Me-Ti melt. The wetting of $\mathrm{TiC}_{x}$ by non-reactive metals like $\mathrm{Au}, \mathrm{Ag}$, and $\mathrm{Sn}$ is affected significantly by the Ti/C ratio (the contact angle decreases with decreasing $x$ value [33]. The detailed thermodynamic calculation was performed in [34]. The calculated titanium carbide compositions $\left(x\right.$ in $\mathrm{TiC}_{x}$ ) as a function of the Ti content in the different Me-Ti liquid solutions are shown in Figure 18. At equal titanium concentration, the lowest $x$ value is associated with the Sn-Ti liquid solution and the highest with the Au-Ti melt. These results are consistent with the level of the negative departure the liquid solutions form ideally. The activity of titanium in the Au-Ti melt is significantly lower than in the Sn-Ti and Ag-Ti liquid solutions [35]-[37]. As mentioned, the equilibrium contact angle de- 
creases with decreasing value of $x$ and it is clear that for the same value of the contact angle, the titanium concentration in liquid Au has to be significantly higher than in liquid Sn and Ag. The results of the thermodynamic analysis are in a good agreement with the experimental results (Figure 14).

Titanium dissolved in liquid $\mathrm{Cu}$ may react directly with boron present in the boron carbide at the interface as well as with the dissolved boron in the melt. In both cases the composition of the system is located in the first phase region (I) where $\mathrm{TiB}_{2}+$ graphite $+\mathrm{B}_{4} \mathrm{C}$ are in equilibrium. Direct reaction of $\mathrm{Ti}$ and $\mathrm{B}_{4} \mathrm{C}$ apparently takes place at the triple line; the metal drop spreads and wetting is achieved thanks to the formation of the $\mathrm{TiB}_{2}$ layer. However, molten $\mathrm{Cu}$ continues to dissolve boron from the substrate, free carbon is liberated, and the initial $\mathrm{TiB}_{2}$ layer is detached from the substrate. The absence of Ti below the "lace" (Figure 19) suggests that boron in the melt reacts with dissolved titanium and the new reaction products attach themselves to the already detached titanium diboride layer, resulting in the coarsening and convolution of the latter. Since the convoluted and detached $\mathrm{TiB}_{2}$ layer is clearly longer than the length of the substrate to which it was attached, we must conclude that the additional quantity of $\mathrm{TiB}_{2}$ that was formed while the layer was floating in the melt, contributed not only to the thickening but also to the lengthening of the layer. The absence of $\mathrm{TiB}_{2}$ particles, other than the convoluted layer, in the melt suggests that the activation energy for the nucleation of such particles in the melt is high and there is significant surface energy benefit for newly formed $\mathrm{TiB}_{2}$ to contribute to the growth of the existing layer rather than to the nucleation of new particles. It must be mentioned that due to the extremely high affinity of titanium to boron, the formation of TiC doesn't take place, even though free carbon is present in the vicinity of the boron carbide substrate.

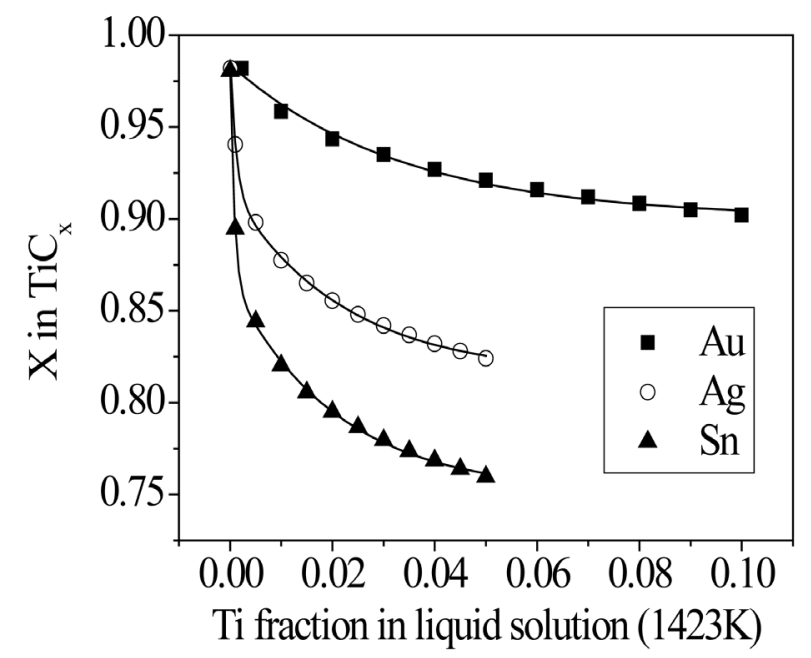

Figure 18. The composition of titanium carbide that coexists in equilibrium with different $\mathrm{Me}=(\mathrm{Au}, \mathrm{Ag}, \mathrm{Sn})$ - $\mathrm{Ti}$ melts at $1423 \mathrm{~K}$.
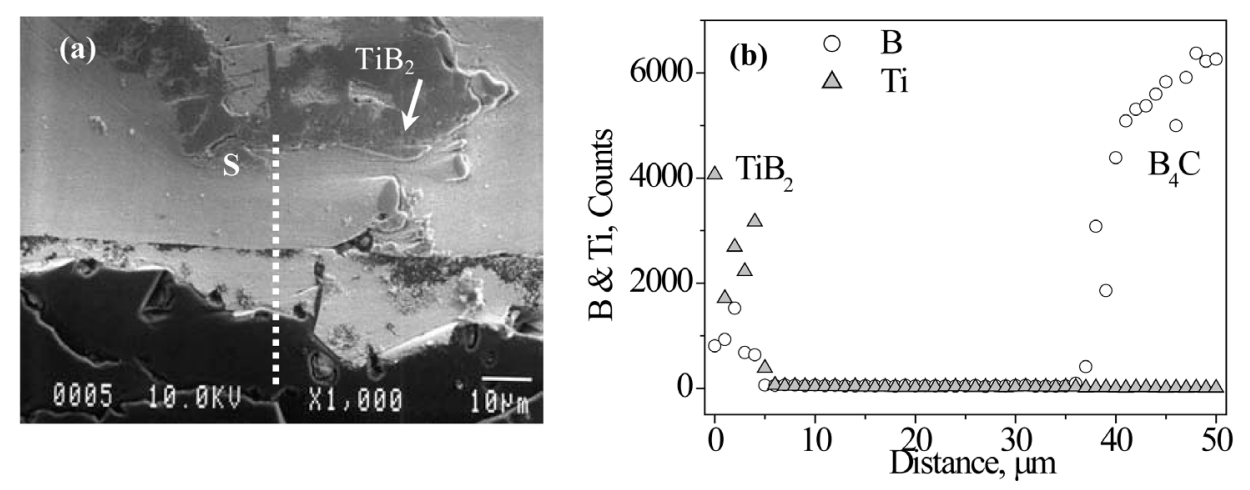

Figure 19. Titanium distribution between the $\mathrm{TiB}_{2}$ convoluted "lace" and the $\mathrm{B}_{4} \mathrm{C}$ substrate, SEM micrograph (a); WDS line scan (b) showing that the Ti concentration between $\mathrm{TiB}_{2}$ and $\mathrm{B}_{4} \mathrm{C}$ is practically zero. 
There is a resemblance between the $\mathrm{B}_{4} \mathrm{C} / \mathrm{Cu} \mathrm{Cu}$-Ti systems, and $\mathrm{B}_{4} \mathrm{C} / \mathrm{Ni}$, Ni-Ti systems, which were studied by Lin \& Sui [4] [5]. Molten Ni dissolves boron carbide but improved wetting isn’t obtained. The addition of Ti reduces the contact angle due to the formation of $\mathrm{TiB}_{2}$ at the substrate/molten drop interface.

\subsection{The Boron Carbide/( $\mathrm{Me}-\mathrm{Al}, \mathrm{Me}=\mathrm{Cu}, \mathrm{Sn})$ Systems}

Among the reactive elements that were added to the non-reactive metals in order to improve wetting, $\mathrm{Al}$, in addition to $\mathrm{Si}$ and $\mathrm{Ti}$, was also used in this study. Whereas Si forms stable carbide and Ti forms a stable boride in contact with boron carbide, $\mathrm{Al}$ forms a ternary aluminum-boron-carbon phase in contact with boron carbide.

\subsubsection{Spreading and Interface Characterization}

The equilibrium contact angles as a function of $\mathrm{Al}$ content in the melts are presented in Figure 20.

A non-monotonous change of the contact angle in the $\mathrm{B}_{4} \mathrm{C} /(\mathrm{Cu}-\mathrm{Al})$ was observed. SEM images of the interfaces between $\mathrm{B}_{4} \mathrm{C}$ and $\mathrm{Cu}$ alloys with various $\mathrm{Al}$ contents are presented in Figure 21.

A small crater filled with graphite precipitates is observed beneath the solidified drop with 19 at\% $\mathrm{Al}$ (Figure 21(a)). A similar, but deeper crater was observed at the interface between pure $\mathrm{Cu}$ and the boron carbide substrate. For Al contents greater than 25 at\%, a new phase is formed at the interface (Figure 21(b), Figure 21(c)). The thickness of the interface layer is about 3 - $5 \mu \mathrm{m}$. Evidently, this new phase promotes spreading and prevents the formation of the crater beneath the liquid drop. According to the WDS analysis, the composition of this phase corresponds to $\mathrm{Al}_{8} \mathrm{~B}_{4} \mathrm{C}_{7}$.

The formation of aluminum borocarbides at the $\mathrm{B}_{4} \mathrm{C} / \mathrm{Al}$ interface was also reported by Lin et al. [38].

For the alloys containing a high aluminum content ( 83 at\%), the presence of the aluminum boride and aluminum carbide phases, which have probably been formed during cooling, were detected within the solidified drop (Figure 21(c)). The presence of the ternary $\mathrm{Al}_{8} \mathrm{~B}_{4} \mathrm{C}_{7}$ phase for the Sn-alloys with an $\mathrm{Al}$ content greater than 5 at $\%$ was also detected in the $\mathrm{B}_{4} \mathrm{C} /(\mathrm{Sn}-\mathrm{Al})$ system. The interface layer in this system is significantly thinner (about 0.5 $\mu \mathrm{m})$ than in the $\mathrm{B}_{4} \mathrm{C} /(\mathrm{Cu}-\mathrm{Al})$ system.

A non-monotonous change of the contact angle in the $\mathrm{B}_{4} \mathrm{C} /(\mathrm{Cu}-\mathrm{Al})$ system was observed for $\mathrm{Al}$ content less than 20 at\% (Figure 20). This feature may be related to the formation of the crater at the interface, which is filled by graphite precipitates. The formation of a deep crater at the $\mathrm{B}_{4} \mathrm{C} / \mathrm{Cu}$ interface has been discussed previously and was attributed to the possibility of liquid $\mathrm{Cu}$ to dissolve a large quantity of boron, while the solubility of carbon in liquid $\mathrm{Cu}$ is extremely low. For the $\mathrm{B}_{4} \mathrm{C} / \mathrm{Cu}$ system the macroscopic contact angle of about $110^{\circ}$ was observed. This contact angle was considered as the apparent one and its value depends on the crater geometry. Evidently, aluminum addition to liquid $\mathrm{Cu}$ reduces the activity of $\mathrm{Cu}$, the crater becomes shallow, and the apparent contact angle increases. Only when the formation of the interfacial layer takes place (at higher alumi num content) does the contact angle decrease. The differences in the spreading kinetics and in the thicknesses

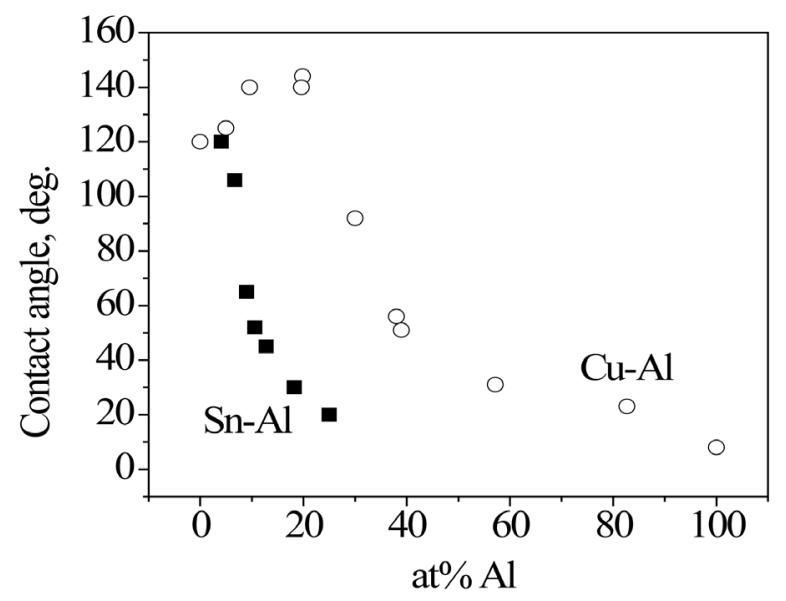

Figure 20. The contact angle in the $\mathrm{B}_{4} \mathrm{C} / \mathrm{Cu}-\mathrm{Al}$ and $\mathrm{B}_{4} \mathrm{C} / \mathrm{Sn}$ $\mathrm{Al}$ systems at $1423 \mathrm{~K}$ as a function of $\mathrm{Al}$ content. 

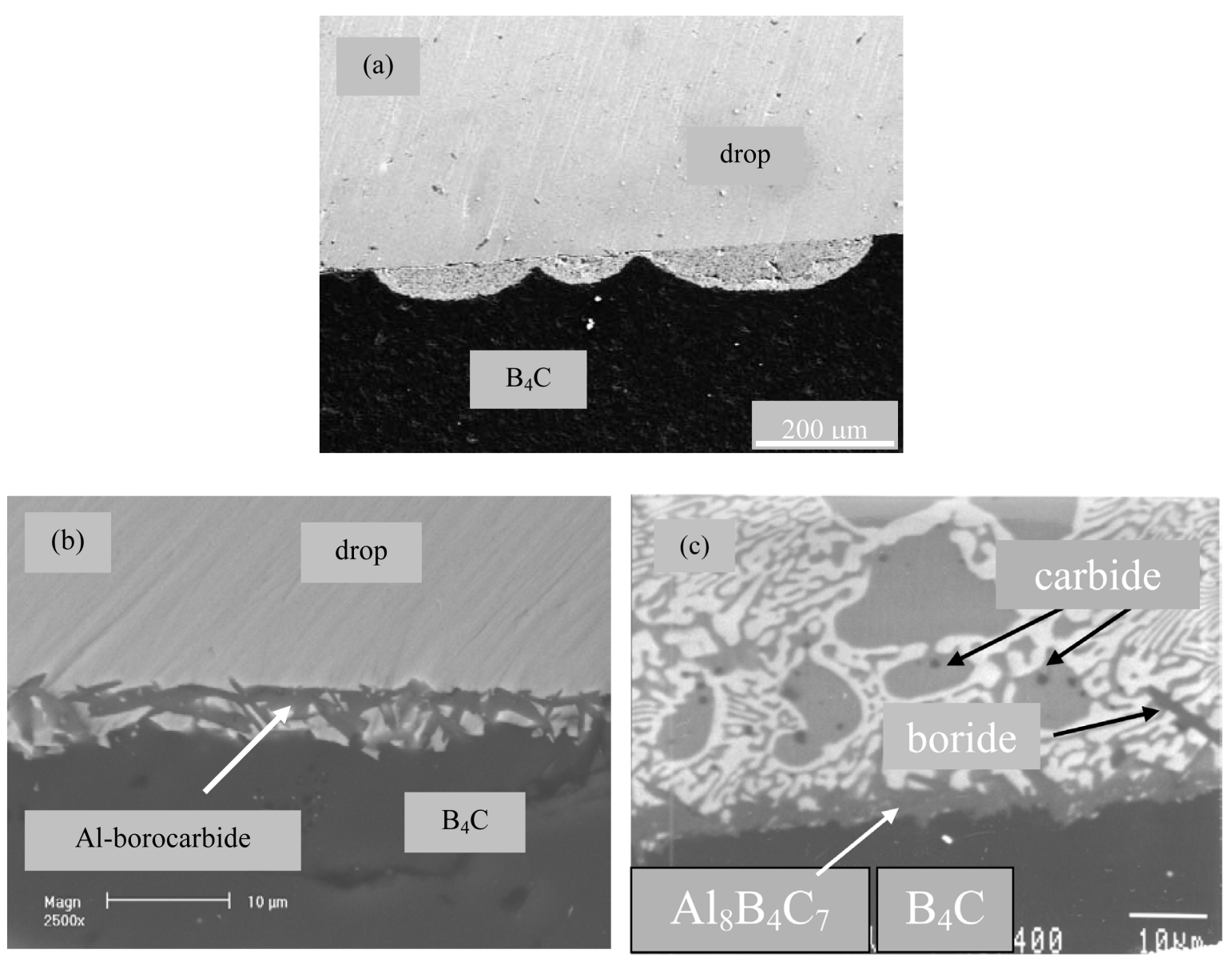

Figure 21. The $\mathrm{B}_{4} \mathrm{C} / \mathrm{Cu}-\mathrm{Al}$ interface structure. $\mathrm{Cu}-19$ at $\% \mathrm{Al}(\mathrm{a})$; $\mathrm{Cu}-40$ at\% $\mathrm{Al}$ (b); $\mathrm{Cu}-83$ at\% $\mathrm{Al}$ (c). The reaction product at the interface was identified as $\mathrm{Al}_{8} \mathrm{~B}_{4} \mathrm{C}_{7}$. Aluminum carbide and boride inclusions were detected in the solidified drop with high $\mathrm{Al}$ contents.

of the interfacial layers for the $\mathrm{B}_{4} \mathrm{C} /(\mathrm{Sn}-\mathrm{Al})$ and $\mathrm{B}_{4} \mathrm{C} /(\mathrm{Cu}-\mathrm{Al})$ systems may be also attributed to the boron solubility in the melts. It could be suggested that the interaction at the interface starts from the boron carbide phase decomposition and dissolution of carbon and boron in the melt. This initial stage of the interaction is more promising for the $\mathrm{Cu}-\mathrm{Al}$ melt because the boron solubility in liquid $\mathrm{Cu}$ is significantly higher and the boron transfer from the substrate to the liquid is faster.

\subsubsection{Discussion}

According to the experimental observations, the wetting behavior in both the $\mathrm{B}_{4} \mathrm{C} /(\mathrm{Sn}-\mathrm{Al})$ and $\mathrm{B}_{4} \mathrm{C} /(\mathrm{Cu}-\mathrm{Al})$ systems is controlled by the formation of the ternary carbide phase at the interface. However, the effect of aluminum additions for the $\mathrm{B}_{4} \mathrm{C} /(\mathrm{Sn}-\mathrm{Al})$ system is stronger than for the $\mathrm{B}_{4} \mathrm{C} /(\mathrm{Cu}-\mathrm{Al})$ system. The reason for these differences may be accounted for by thermodynamic properties of the $\mathrm{Cu}-\mathrm{Al}$ and $\mathrm{Sn}-\mathrm{Al}$ alloys. It was established that the $\mathrm{Cu}-\mathrm{Al}$ liquid solution displays a negative departure from ideality, while for the Sn-Al liquid solution this departure is positive [39] [40]. A dominant effect of the thermodynamic properties of the alloys on the wetting behavior is illustrated in Figure 22 where the equilibrium contact angle is plotted as a function of aluminum activity.

\section{Summary and Conclusions}

The present report summarizes a comprehensive study concerning the wetting properties of $\mathrm{B}_{4} \mathrm{C}$ by non-reactive metals ( $\mathrm{Cu}, \mathrm{Au}, \mathrm{Ag}, \mathrm{Sn})$. Since these metals do not form stable carbides or borides, they are not able to wet $\mathrm{B}_{4} \mathrm{C}$ properly. In order to improve wetting three active elements were selected. These elements are able to promote 


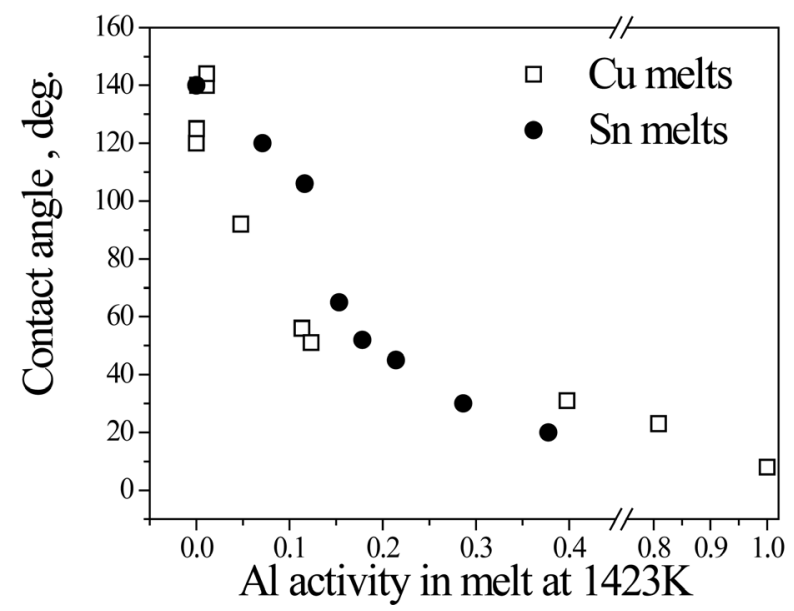

Figure 22. The contact angle in the $\mathrm{B}_{4} \mathrm{C} / \mathrm{Cu}-\mathrm{Al}$ and $\mathrm{B}_{4} \mathrm{C} / \mathrm{Sn}$ $\mathrm{Al}$ systems as a function of the activity of $\mathrm{Al}$ in $\mathrm{Cu}$ and $\mathrm{Sn}$ melts at $1423 \mathrm{~K}$.

wetting by the formation of new phases at the ceramic/drop interface, according to three different expected reactions:

- The addition of Si, which has relatively high affinity to C, leads to SiC formation and changing the boron carbide composition towards lower carbon content.

- The addition of $\mathrm{Ti}$, which displays extremely high affinity to $\mathrm{B}$, leads to $\mathrm{TiB}_{2}$ formation and free carbon precipitation at the interface.

- The addition of Al, which allows forming borocarbide phases at the interface.

In contrast with other investigated non-reactive metals, liquid $\mathrm{Cu}$ dissolves $20-25$ at $\%$ of $\mathrm{B}$. When boron was used as alloying addition to $\mathrm{Cu}$, the formation of new phases at the interface was prevented and the effect of boron addition on the wetting behavior was attributed to an altering of the boron carbide composition in contact with boron-containing melts. It was also established that the most important properties of boron carbide that affect the wetting phenomena are the relatively low chemical stability and the existence of a wide composition range. The first property determines the possibility of boron carbide to react with liquid metals (by dissolution or formation of new phases) and the second offers an additional degree of freedom to improve its wetting by changing the composition of the ceramic phase.

\section{Acknowledgements}

This work was partly supported by the Israel Science Foundation grant 118/03.

\section{References}

[1] Halverson, D.C., Pyzik, A.J., Aksay, I.A. and Snowden, W.E. (1989) Processing of Boron Carbide-Aluminum Composites. Journal of the American Ceramic Society, 72, 775-780. http://dx.doi.org/10.1111/j.1151-2916.1989.tb06216.x

[2] Jung, J. and Kang, S. (2004) Advances in Manufacturing Boron Carbide-Aluminum Composites. Journal of the American Ceramic Society, 87, 47-54. http://dx.doi.org/10.1111/j.1551-2916.2004.00047.x

[3] Toptan, F., Kilicarslan, A., Karaaslan, A., Cigdem, M. and Kerti, I. (2010) Processing and Microstructural Characterisation of AA 1070 and AA 6063 Matrix B 4 Cp Reinforced Composites. Materials \& Design, 31, S87-S91. http://dx.doi.org/10.1016/j.matdes.2009.11.064

[4] Lin, Q. and Sui, R. (2013) Wetting of $\mathrm{B}_{4} \mathrm{C}$ by Molten Ni at 1753 K. Journal of Alloys and Compounds, 556, $274-279$.

[5] Lin, Q. and Sui, R. (2013) Wetting of $\mathrm{B}_{4} \mathrm{C}$ by Molten Ni-Ti Alloys at $1753 \mathrm{~K}$. Journal of Alloys and Compounds, 577, 37-43. http://dx.doi.org/10.1016/j.jallcom.2013.04.164

[6] Li, J.G. (1994) Wetting of Ceramic Materials by Liquid Silicon, Aluminium and Metallic Melts Containing Titanium and Other Reactive Elements: A Review. Ceramics International, 20, 391-412.

[7] Eustathopoulos, N., Nicholas, M.G. and Devet, B. (1999) Wettability at High Temperatures. Pergamon Materials Se- 
ries, Oxford.

[8] Delannay, F., Froyen, L. and Deruyttere, A. (1986) The Wetting of Solids by Molten Metals and Its Relation to the Preparation of Metal-Matrix-Composites. Journal of Materials Science, 22, 1-16. http://dx.doi.org/10.1007/BF01160545

[9] Liu, G.W., Muolo, M.L., Valenza, F. and Passerone, A. (2010) Survey on Wetting of SiC by Molten Metals. Ceramics International, 36, 1177-1188. http://dx.doi.org/10.1016/j.ceramint.2010.01.001

[10] Marin, J., Olivares, L., Ordonez, S. and Martinez, V. (2003) Wetting of Silicon Carbide by Cu-Si Alloys. Materials Science Forum, 416-418, 487-492. http://dx.doi.org/10.4028/www.scientific.net/MSF.416-418.487

[11] Rado, C., Kalogeropoulou, S. and Eustathopoulos, N. (2000) Bonding and Wetting in Non Reactive Metal/SiC Systems: Weak or Strong Interfaces? Materials Science \& Engineering: A, 276, 195-202. http://dx.doi.org/10.1016/S0921-5093(99)00274-9

[12] Froumin, N., Frage, N., Polak, M. and Dariel, M.P. (1997) Wettability and Phase Formation in the $\mathrm{TiC}_{x} / \mathrm{Al}$ System. Scripta Materialia, 37, 1263-1267. http://dx.doi.org/10.1016/S1359-6462(97)00235-2

[13] Kharlamov, A.I., Loichenko, S.V., Nizehenko, V.I., Kirllova, N.V. and Floka, L.I. (2001) Wetting of Hot-Pressed Aluminum Borides and Borocarbides by Molten Aluminum and Copper. Powder Metallurgy and Metal Ceramics, 40, 65-70. http://dx.doi.org/10.1023/A:1011364023572

[14] Muolo, M.L., Ferrera, E., Novakovic, R. and Passerone, A. (2003) Wettability of Zirconium Diboride Ceramics by Ag, $\mathrm{Cu}$, and Their Alloys with Zr. Scripta Materialia, 48, 191-196. http://dx.doi.org/10.1016/S1359-6462(02)00361-5

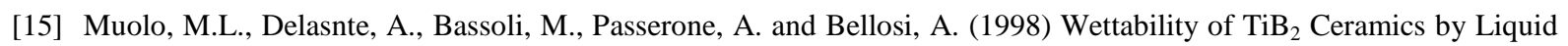
$\mathrm{Cu}$, and Ag-Cu Eutectic Alloys. Interfacial Science in Ceramic Joining, NATO ASI Series, 58, 87-94.

[16] Aizenshtein, M., Froumin, N., Barth, P., Shapiro-Tsoref, E., Dariel, M.P. and Frage, N. (2007) How Does the Composition of Quasi-Stoichiometric Titanium Diboride Affect Its Wetting by Molten $\mathrm{Cu}$ and Au? Journal of Alloys and Compounds, 442, 375-378. http://dx.doi.org/10.1016/j.jallcom.2006.06.117

[17] Elliott, R.P. (1961) The Boron Carbon System. Final Technical Report ARF-2200-12. US Atomic Energy Commission, Chicago.

[18] Beauvy, M. (1983) Stoichiometric Limits of Carbon-Rich Boron Carbide Phases. Journal of Less Common Metals, 90, 169-175. http://dx.doi.org/10.1016/0022-5088(83)90067-X

[19] Thevenot, F. (1990) Boron Carbide-A Comprehensive Review. Journal of the European Ceramic Society, 6, $205-225$. http://dx.doi.org/10.1016/0955-2219(90)90048-K

[20] Naidich, Ju.V. (1981) The Wettability of Solids by Liquid Metals. Progress in Surface and Membrane Science, 14, 353-484. http://dx.doi.org/10.1016/B978-0-12-571814-1.50011-7

[21] Oden, L.L. and Gokcen, N.A. (1992) Cu-C and Al-Cu-C Phase Diagrams and Thermodynamic Properties of $\mathrm{C}$ in the Alloys from $1550^{\circ} \mathrm{C}$ to $2300^{\circ} \mathrm{C}$. Metallurgical Transactions B, 23, 453-458. http://dx.doi.org/10.1007/BF02649664

[22] Massalski, T.B., Subramanian, P.R., Okamoto, H. and Kacprazak, L. (1990) Binary Alloy Phase Diagrams. 2nd Edition, ASM International, Materials Park.

[23] Frage, N., Froumin, N., Aizenshtein, M. and Dariel, M.P. (2004) Interface Reaction in the B ${ }_{4} \mathrm{C} /(\mathrm{Cu}-\mathrm{Si})$ System. Acta Materialia, 52, 2625-2635. http://dx.doi.org/10.1016/j.actamat.2004.02.010

[24] Froumin, N., Frage, N., Aizenshtein, M. and Dariel, M.P. (2003) Ceramic-Metal Interaction and Wetting Phenomena in the $\mathrm{B}_{4} \mathrm{C} / \mathrm{Cu}$ System. Journal of the European Ceramic Society, 23, 2821-2828. http://dx.doi.org/10.1016/S0955-2219(03)00294-2

[25] Young, T. (1805) An Essay on the Cohesion of Fluids. Philosophical Transactions of the Royal Society of London, 95, 65-87. http://dx.doi.org/10.1098/rstl.1805.0005

[26] Dupré, M.A. (1869) Theories Mecanique de la Chaleur. Gauthier Villars, Imprimeur-Librarie, Paris.

[27] Frage, N., Froumin, N. and Dariel, M.P. (2002) Wetting of TiC by Non-Reactive Liquid Metals. Acta Materialia, 50, 237-245. http://dx.doi.org/10.1016/S1359-6454(01)00349-4

[28] Seifert, H.J. and Aldinger, F. (2002) Phase Equilibria in the Si-B-C-N System. High Performance Non-Oxide Ceramics I. Structure and Bonding, 101, 1-58. http://dx.doi.org/10.1007/3-540-45613-9 1

[29] Hillert, M. (1988) Phase Equilibria, Fhase Diagram and Phase Transformation-Their Thermodynamic Basis. Cambridge University Press, Cambridge.

[30] Tsoga, A., Ladas, S. and Nikolopoulos, P. (1997) Correlation between the Oxidation State of $\alpha$-SiC and Its Wettability with Non-Reactive (Sn) or Reactive (Ni) Metallic Components and Their Binary Si-Alloy. Acta Materialia, 45, 35153525. http://dx.doi.org/10.1016/S1359-6454(97)00044-X 
[31] Drevet, B., Kalogeropoulou, S. and Eustathopoulos, N. (1993) Wettability and Interfacial Bonding in Au-Si/SiC System. Acta Metallurgica et Materialia, 41, 3119-3126. http://dx.doi.org/10.1016/0956-7151(93)90041-P

[32] Gusev, A.I. (1997) Phase Equilibria in the Ternary System Titanium-Boron-Carbon: The Sections $\mathrm{TiC}_{y}-\mathrm{TiB}_{2}$ and $\mathrm{B}_{4} \mathrm{C}_{y^{-}}$ $\mathrm{TiB}_{2}$. Journal of Solid State Chemistry, 133, 205-210. http://dx.doi.org/10.1006/jssc.1997.7429

[33] Frage, N., Froumin, N., Aizenshtein, M., Kutsenko, L., Fuks, D. and Dariel, M.P. (2005) Reactive Wetting in Titanium Carbide/Non-Reactive Metal Systems. Current Opinion in Solid State and Materials Science, 9, 189-195. http://dx.doi.org/10.1016/j.cossms.2006.02.008

[34] Aizenshtein, M., Froumin, N., Frage, N. and Dariel, M.P. (2005) Interface Interaction and Wetting Behavior in $\mathrm{B}_{4} \mathrm{C} /$ (Me-Ti) Systems (Me=Cu, Ag, Sn and Au). Materials Science \& Engineering: A, 395, 180-185. http://dx.doi.org/10.1016/j.msea.2004.12.017

[35] Kleppa, O.J. and Topor, L. (1985) Thermochemistry of Binary Liquid Gold Alloys: (Gold + Chromium), (Gold + Vanadium), (Gold + Titanium), and (Gold + Scandium) at 1379 K. Metallurgical Transactions A, 16A, 93-99.

[36] Pan, W., Li, R.T., Chen, J., Sun, R.F. and Lian, J. (2000) Thermodynamic Properties of Ti in Ag-Ti Alloys. Materials Science \& Engineering: A, 287, 72-77. http://dx.doi.org/10.1016/S0921-5093(00)00821-2

[37] Nikolaenko, I.V., Beloborodova, E.A., Batalin, G.I. and Zhuravlev, V.S. (1984) Heats of Dissolution of Titanium in TinTitanium Melts. Zhurnal Fizicheskoi Khimii, 58, 2873-2876.

[38] Lin, Q.L., Shen, P., Qiu, F., Zhang, D. and Jiang, Q.C. (2009) Wetting of Polycrystalline $\mathrm{B}_{4} \mathrm{C}$ by Molten Al at $1173-$ 1473 K. Scripta Materialia, 60, 960-963. http://dx.doi.org/10.1016/j.scriptamat.2009.02.024

[39] Heuzey, M.C. and Pelton, A.D. (1996) Critical Evaluation and Optimization of the Thermodynamic Properties of Liquid Tin Solutions. Metallurgical and Materials Transactions B, 27, 810-828. http://dx.doi.org/10.1007/BF02915611

[40] Ansara, I., Dinsdale, A.T. and Rand, M.H. (1998) Cost 507: Thermochemical Database for Light Metal Alloys. Vol. 2, Office for Official Publications of the European Communities, Luxembourg. 
Scientific Research Publishing (SCIRP) is one of the largest Open Access journal publishers. It is currently publishing more than 200 open access, online, peer-reviewed journals covering a wide range of academic disciplines. SCIRP serves the worldwide academic communities and contributes to the progress and application of science with its publication.

Other selected journals from SCIRP are listed as below. Submit your manuscript to us via either submit@scirp.org or Online Submission Portal.
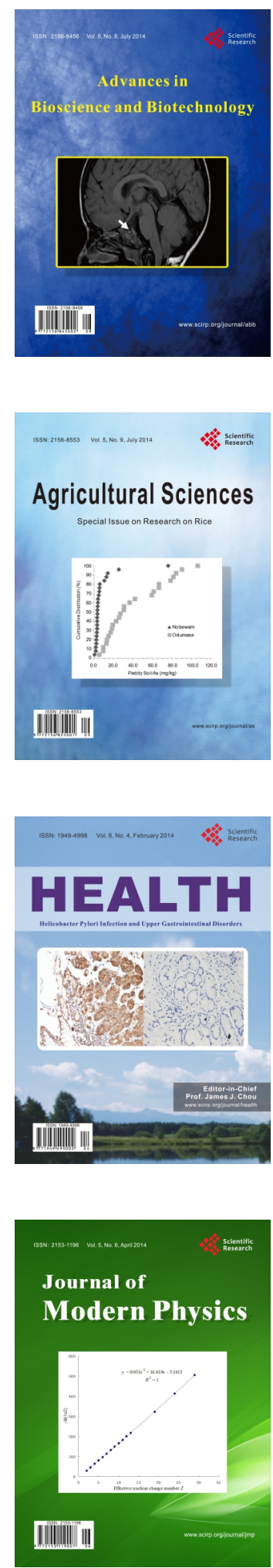
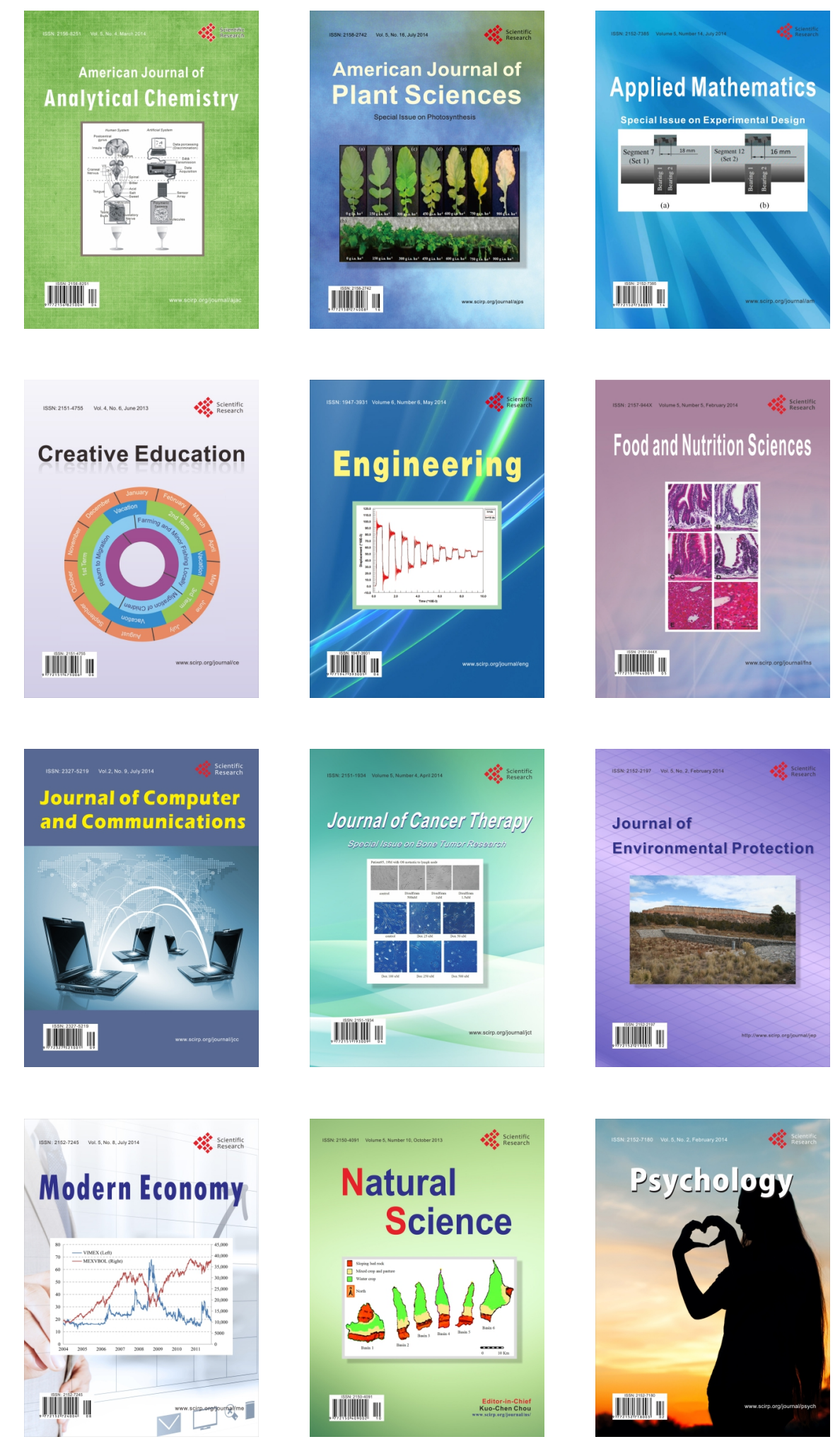